\title{
Evapotranspiration Rates at Selected Sites in the Powder River Basin, Wyoming and Montana
}

By L. W. Lenfest, Jr.

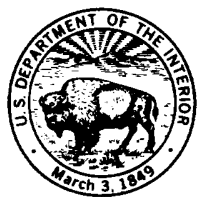




\title{
DEPARTMENT OF THE INTERIOR
}

DONALD PAUL HODEL, SECRETARY

\author{
U.S. GEOLOGICAL SURVEY
}

Dallas L. Peck, Director

For additional information contact:

District Chief

U.S. Geological Survey

2120 Capitol Avenue

P.0. Box 1125

Cheyenne, Wyoming 82003

Telephone: (307) 772-2153
Coples of this report can be purchased from:

U.S. Geologtcal Survey Books and Open-File Reports Federal Center, Bullding 41 Box 25425

Denver, Colorado 80225

Telephone: (303) 236-7476 


\section{CONTENTS}

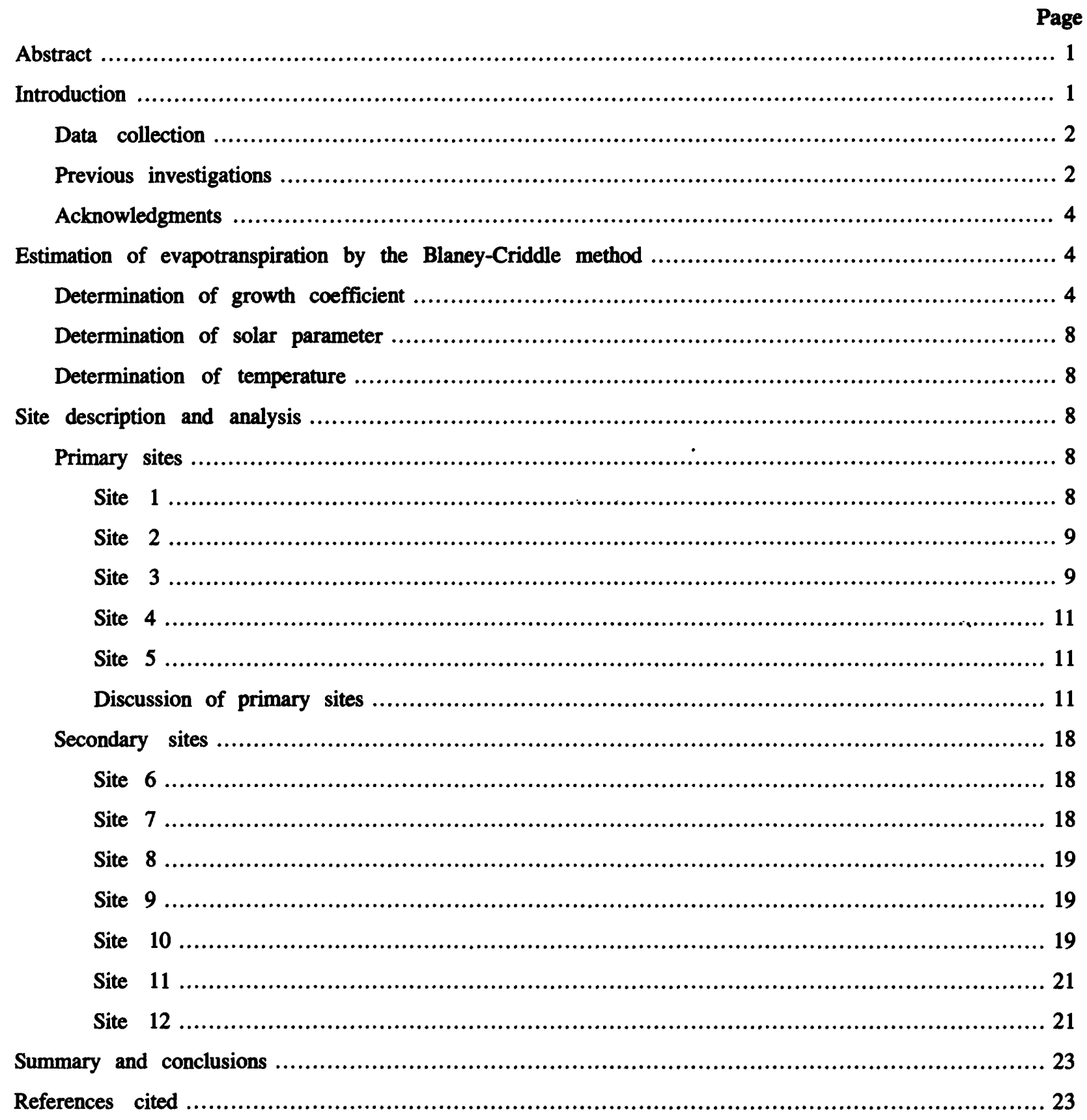




\section{ILLUSTRATIONS}

Figure 1. Map of study area showing location of evapotranspiration sites and

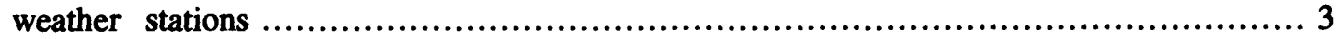

2. Graph showing estimated values of monthly growth coefficients in relation to depth to water .....................................................................6 6

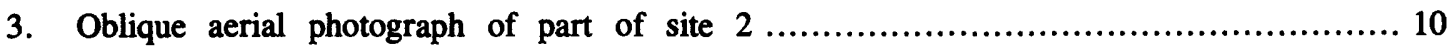

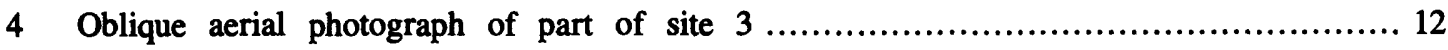

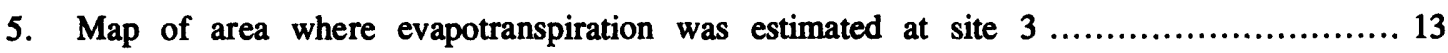

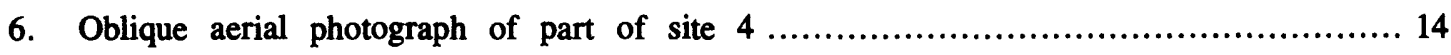

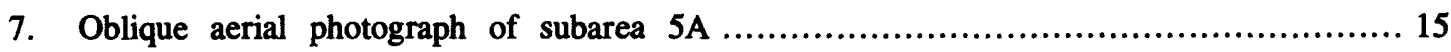

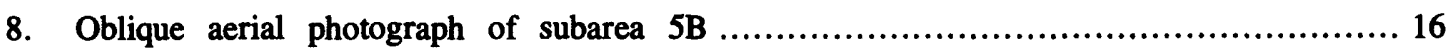

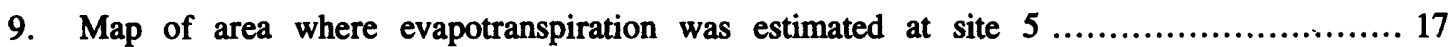

\section{TABLES}

Table

1. Percentages of vegetation at sites where evapotranspiration was estimated

2. Density factors used to compute corrected monthly growth coefficients

3. Average monthly temperatures for the 1978 growing season at sites studied 7

4-9. Computed evapotranspiration at

4. Site 1 9

5. Site 2 10

6. Site 3 12

7. Site 4 14

8. Subarea $5 \mathrm{~A}$ 15

9. Subarea $5 B$ 16

10. Evapotranspirative discharge from alluvial aquifers at sites 3,4 , and 5 18

11-17. Computed evapotranspiration at

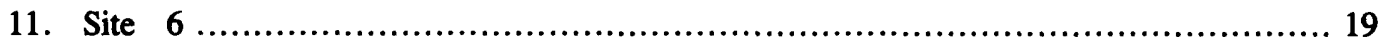

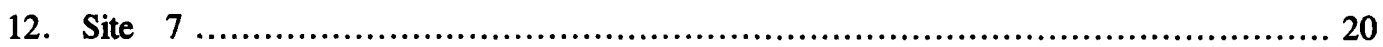

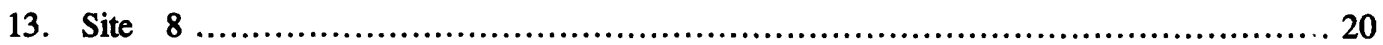

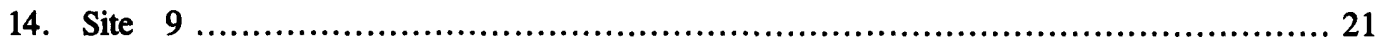

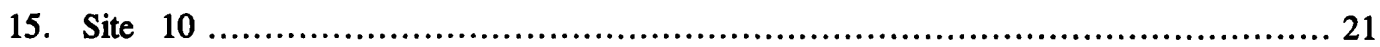

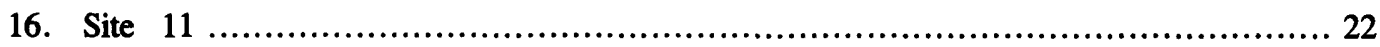

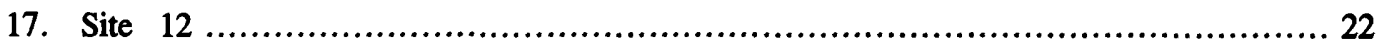




\section{METRIC CONVERSIONS}

For those readers interested in using the metric system, the following table may be used to convert inchpound units of measurement used in this report to metric units:

\section{Multiply}

inch

foot

cubic foot per second $\left(\mathrm{ft}^{3} / \mathrm{s}\right)$

mile

square mile $\left(\mathrm{mi}^{2}\right)$
By

\section{To obtain}

25.4

millimeter

0.3048

meter

$0.02832 \quad$ cubic meter per second

1.609

kilometer

2.590

square kilometer

Temperature can be converted to degrees Fahrenheit $\left({ }^{\circ} \mathrm{F}\right)$ or degrees Celsius $\left({ }^{\circ} \mathrm{C}\right)$ by the following equations:

$$
\begin{aligned}
& { }^{\circ} \mathrm{F}=9 / 5\left({ }^{\circ} \mathrm{C}\right)+32 \\
& { }^{\circ} \mathrm{C}=5 / 9\left({ }^{\circ} \mathrm{F}-32\right)
\end{aligned}
$$




\title{
Evapotranspiration Rates at Selected Sites in the Powder River Basin, Wyoming and Montana
}

\author{
By L. W. Lenfest, Jr.
}

\begin{abstract}
Twelve sites were chosen for a study of evapotranspiration in the Powder River basin based on variations in topography and plant communities, geographic location, and the availability of ground-water data at the sites. Evapotranspiration rates were estimated from ground-water, meteorological, and vegetation data using the BlaneyCriddle method.

Five of the sites were equipped with digital recorders that provided continuous ground-waterlevel data at the sites for the 1978 growing season. Evapotranspiration was estimated monthly during the growing season and ranged from 0 to 3.7 inches per month. Total evapotranspiration rates for the growing season ranged from 8.3 to 14.9 inches. Discharge per mile of stream reach was estimated for three of the sites and ranged from 0.03 to 0.31 cubic foot per second.

The well records for the remaining seven sites consisted of monthly, or less frequent, water-level measurements. Evapotranspiration rates estimated for those months for which water-level data were available ranged from 0 to 3.8 inches per month. Only one of these sites had monthly water-level measurements for the entire growing season; a total of 9.7 inches of evapotranspiration was estimated for the growing season at this site.
\end{abstract}

\section{INTRODUCTION}

The estimation of evapotranspirative discharge from aquifers in the Powder River basin is part of a comprehensive study of the ground-water resources within the Northern Great Plains area of Wyoming, Montana, North Dakota, and South Dakota. A digital ground-water model of the area is being developed that requires estimates of outflow from and inflow to the ground-water system. Evapotranspiration can account for a significant part of the outflow in the water budget of a natural hydrologic system. Decreasing surface-water discharge and declining ground-water levels during the growing season can be attributed at least in part to evapotranspiration. Observations of ground-water levels and stream discharge at the Powder River at Arvada, Wyo., in 1962 illustrate these declines (Whitcomb and others, 1966, p. 53). The purpose of this report is to provide information on evapotranspiration as one component of discharge from the alluvial ground-water system.

Evapotranspiration is the consumptive use of water by plant communities, combined with direct evaporation from moist soil and free-water surfaces. The rate of evapotranspiration, defined as the quantity of evapotranspiration in inches per unit area for a specified time, is affected by the type of plant community, availability of soil moisture, density and type of plant cover, temperature, solar 
radiation, wind, and humidity. Evapotranspirative discharge is defined in this report as the rate of ground water, in cubic feet per second, discharged from alluvial aquifers through evapotranspiration. Evapotranspiration usually is discussed in terms of actual or potential evapotranspiration, and it is important to distinguish between the two. Potential evapotranspiration is usually expressed in terms of irrigation requirements and is the quantity of evapotranspiration that would be evapotranspired from an area with uniform plant cover if the plant community is not stressed by a lack of water. Actual evapotranspiration, the subject of this report, is the quantity of evapotranspiration produced by areas and plant communities under existing conditions.

Estimates of actual discharges by evapotranspiration from alluvial aquifers in the Powder River basin of Wyoming and Montana are used in this report. Potential-evapotranspiration rates discussed by Toy and Munson (1978) and Trelease and others (1970) are inherently greater than the actual rates estimated in this report and are used as an upper-limit check.

The study of evapotranspiration in this report is limited to the alluvial valleys within the Powder River structural basin of northeastern Wyoming and southeastern Montana (fig. 1) because streams in alluvial valleys are the major discharge areas of bedrock aquifers. Also, high-altitude infrared imagery from the earth-orbiting Landsat satellite indicates that the largest concentration of vegetation producing evapotranspiration occurs in alluvial valleys along streams. The study area is bounded on the south by the Laramie Mountains, on the west by the Bighorn Mountains, and on the north by the Yellowstone River. The eastern boundary is approximately 25 miles west of the Black Hills. Major drainages in the basin include the Powder River, the Tongue River, Rosebud Creek, the Cheyenne River, and the Belle Fourche River. The topography of the basin is predominantly rolling plains that become increasingly hilly to the northeast.

\section{Data Collection}

Data in the form of ground-water-level observations and infrared photographs were collected and analyzed at 12 sites within the study area. Evapotranspiration depends on the depth to water; evapo- ration and plant transpiration during the growing season increase as the ground-water level gets closer to the land surface. Infrared photographs were used as an indication of where evapotranspiration occurs and at what depth the different plant species stop obtaining water from aquifers. The 12 sites, which comprise 5 primary sites and 7 secondary sites, were chosen based on variations in topography, plant-community type, geographic location, and availability of ground-water-level data.

Water-level data were collected at the primary sites $(1,2,3,4$, and 5$)$ using digital recorders in one or more wells at each site. Monthly evapotranspiration rates were estimated and totaled for the 1978 growing season. Infrared photographs of sites 3 and 4 provided data for plotting areas of evapotranspiration on maps, and discharge was calculated by multiplying the plotted areas by the rate of evapotranspiration. Data were collected at two small subareas, $5 \mathrm{~A}$ and $5 \mathrm{~B}$, within site 5 because of different vegetation densities; evapotranspiration rates calculated for the two subareas were averaged, resulting in a representative evapotranspiration rate for site 5 . Infrared photographs of subareas $5 A$ and $5 \mathrm{~B}$ provided data for plotting areas of evapotranspiration at site 5 on maps, and discharge was calculated by multiplying the plotted area at site 5 by the average rate of evapotranspiration.

Data for the secondary sites (6-12) consist of periodic, usually monthly, measurements of water levels in wells at the sites. Evapotranspiration rates were estimated for months for which data were available. A seasonal evapotranspiration rate was calculated for site 8 which had water-kevel data for the entire 1978 growing season.

\section{Previous Investigations}

Lauenroth and Sims (1976) studied evapotranspiration of natural vegetation characteristic of the short-grass prairie of northeastern Colorado and determined actual evapotranspiration rates. Their results were used by Toy and Munson (1978) to calculate the Blaney-Criddle seasonal-growth coefficient for natural vegetation in a report discussing potential evapotranspiration in the Powder River Basin. Trelease and others (1970) used the BlaneyCriddle method in a report that estimates potentialevapotranspiration rates throughout Wyoming as a guideline for water use in irrigation. 


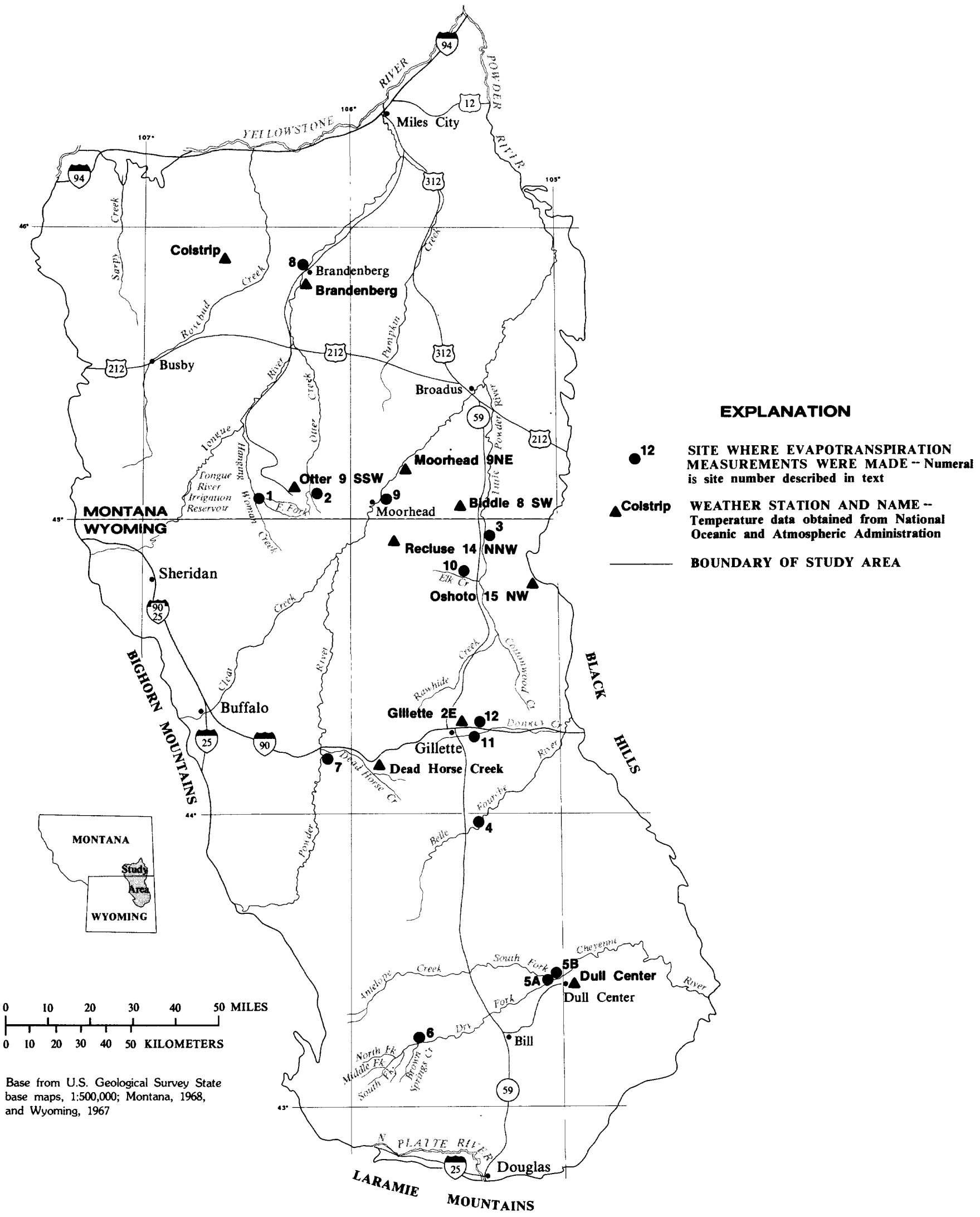

Figure 1 Study area showing location of evapotranspiration sites and weather stations. 


\section{Acknowledgments}

The cooperation and assistance of personnel of the U.S. Soil Conservation Service is gratefully acknowledged. Conversations with Terrance W. Toy, University of Denver, Denver, Colo., and William K. Lauenroth, Colorado State University, Fort Collins, Colo., also were constructive in the preparation of this report.

\section{ESTIMATION OF EVAPOTRANSPIRATION BY THE BLANEY-CRIDDLE METHOD}

Various methods have been developed for correlating evapotranspiration with geographic location, climate, and type of vegetation. The BlaneyCriddle method (Blaney and Criddle, 1962) was chosen because data required for this method are more easily obtained than data required for other methods, and the modifications by Rantz (1968) provide realistic estimates of evapotranspiration rates in a natural environment. Further, the Blaney-Criddle method compares well with other accepted techniques for determining evapotranspiration (Cruff and Thompson, 1967, p. M1, M2).

The Blaney-Criddle method was originally developed to estimate irrigation requirements for crops where the plant community contains one species, the water supply does not fluctuate appreciably, and the plant growth is relatively dense. Rantz modified the method for specific application to phreatophytes by considering variations in type of vegetation, density of growth, and depth to the water table. Although the tree grouping contained the only true phreatophyte in the study area, it was assumed that the other groupings were similar to phreatophytes as long as they had a water supply.

The equation for estimating potential evapotranspiration for the entire growing season (Blaney and Criddle, 1962, p. 1) is

$\mathrm{U}=\mathrm{KF}$

where $U=$ seasonal use of water through evapotranspiration, in inches; $K$ = seasonal growth coefficient, dimensionless; and $\mathrm{F}$ = environment factor, $\Sigma[(p \times t) / 100]$.

Ample moisture is assumed. Coefficient $p$ is the solar parameter representing the monthly mean percentage of annual daylight hours, and coefficient $t$ is the mean monthly temperature, in degrees Fahrenheit.

The equation for monthly potential evapotranspiration is

$\mathrm{U}_{\mathrm{m}}=\mathrm{K}_{\mathrm{m}} \mathrm{F}_{\mathrm{m}}$

where $U_{m}=$ monthly use of water through evapotranspiration, in inches; $\mathrm{K}_{\mathrm{m}}=$ monthly growth coefficient, dimensionless; and $F_{m}=(p \times t) / 100$.

\section{Determination of Growth Coefficient}

The monthly growth coefficient for a site is affected by the composition of the plant community, percentage of ground cover, density of the vegetation, and depth to ground water. Individual species were grouped according to three naturally occuring vegetation types: grass, brush, and trees. Cottonwoods, and a smaller proportion of willows, dominate the tree population and are the only true phreatophytes considered within the study area. Wheatgrass is the major constituent within the grass type of vegetation, along with smaller proportions of needleandthread, needle grass, blue grama, alkali sacaton, and other native grasses. Big sage and silver sage are the dominant species within the brush grouping.

The percentages of natural vegetation by group at each site given in table 1 were obtained from a handbook (U.S. Soil Conservation Service, 1977). The data listed in the handbook are potential classifications by species, according to the precipitation zone and soil type, and are not site specific. The Soil Conservation Service estimates of ground cover listed in table 1 were adjusted using data from aerial photographs of each site. The weighted percentages of ground covered by vegetation (wf) have been adjusted where: (1) Several types of vegetation cover the same area (canopy covers), and (2) aerial photographs showed a significant difference in species population within the plant community from what was initially estimated. Three of the sites $(2,3$, and 9) had cultivated alfalfa fields; the percentage of area under cultivation was estimated from the aerial photographs and considered as a fourth classification of vegetation. 
Table 1. Percentages of vegetation at sites where evapotranspiration was estimated.

[Percentages of ground cover and of natural vegetation from

Soil Conservation Service. Weighted percentages of grass,

trees, and brush by author, using unpublished data from Soil

Conservation Service. Weighted percentage of alfalfa by

author, using aerial photographs]

\begin{tabular}{|c|c|c|c|c|c|c|c|c|}
\hline \multirow[b]{2}{*}{ Site } & \multicolumn{3}{|c|}{$\begin{array}{c}\text { Percentage of natural vegetation } \\
\text { by group }\end{array}$} & \multirow{2}{*}{$\begin{array}{c}\text { Percentage of ground cover } \\
\text { by natural vegetation }\end{array}$} & \multicolumn{4}{|c|}{$\begin{array}{c}\text { Weighted percentage of ground cover } \\
\text { by vegetation } \\
\text { (wf) }\end{array}$} \\
\hline & Grass & Brush & Trees & & Grass & Brush & Trees & Alfalfa \\
\hline \multicolumn{9}{|l|}{ Primary } \\
\hline 1 & 80 & 19 & 1 & 75 & 80 & 30 & 1 & -- \\
\hline 2 & 75 & 24 & 1 & 35 & $\begin{array}{r}50 \\
1 \quad 71\end{array}$ & $\begin{array}{r}17 \\
1 \quad 24\end{array}$ & $\begin{array}{ll} & 1 \\
1 & 1\end{array}$ & $\begin{array}{l}30 \\
--\end{array}$ \\
\hline 3 & 80 & 10 & 10 & 50 & $\begin{array}{r}60 \\
180\end{array}$ & $\begin{array}{r}8 \\
1 \quad 11\end{array}$ & $\begin{array}{r}15 \\
1 \quad 20\end{array}$ & $\begin{array}{l}25 \\
--\end{array}$ \\
\hline 4 & 80 & 20 & -- & 30 & 70 & 35 & -- & -- \\
\hline $5^{2}(5 \mathrm{~A})$ & 75 & 5 & 20 & 55 & 70 & 10 & 35 & -- \\
\hline $2(5 B)$ & 75 & 15 & 10 & 55 & 80 & 15 & 15 & - \\
\hline \multicolumn{9}{|l|}{ Secondary } \\
\hline 6 & 80 & 20 & -- & 25 & 70 & 20 & -- & -- \\
\hline 7 & 75 & 20 & 5 & 45 & 80 & 20 & 10 & $\ldots$ \\
\hline 8 & 80 & 15 & 5 & 50 & 70 & 25 & 5 & -- \\
\hline 9 & 80 & 15 & 5 & 50 & 40 & 8 & 6 & 50 \\
\hline & & & & & 180 & 116 & $\begin{array}{ll}1 & 12\end{array}$ & -- \\
\hline 10 & 80 & 10 & 10 & 45 & 70 & 20 & 20 & -- \\
\hline 11 & 75 & 24 & 1 & 30 & 75 & 15 & 1 & -- \\
\hline 12 & 80 & 15 & 5 & 35 & 80 & 10 & 7 & -- \\
\hline
\end{tabular}

\footnotetext{
1 Weighted percentages of natural ground cover without considering cultivated alfalfa. These are used in determining density factors only and are not used in computing the composite monthly growth coefficient.

2 Percentages of vegetation were calculated at two small subareas within site 5 .
}

Growth-coefficient curves relating the growth coefficient to depth to water (fig. 2) were modified from those developed for trees by Cox and Havens $(1974$, p. E17) and for grass and brush by Rantz (1968, p.D11). Cox and Havens (1974) developed a relation between yearly transpiration rates and depth to water for salt cedar in southeastern New Mexico for a depth range of 2-16 feet below land surface. The curve was converted to relate depth to water to growth coefficients by dividing the yearly transpiration rates $(\mathrm{U})$ for salt cedar by 64.7 , the yearly environment factor $(F)$ for the study area determined by Blaney and Criddle (1962, p. 47). The upper part of the curve compares favorably to the curve developed by Rantz (1968, p. D11) for cottonwoods and willows. The converted curve includes the range in depth to water from 8 to 16 feet below land surface, not computed by Rantz. The Rantz curve for saltgrass, used in this report to represent grass, and the curve for mesquite, used to represent brush, were linearly extended below depths of 8 feet below land surface.
Because the grass and brush considered in this report are not true phreatophytes, infrared photographs of the sites were used to decide at which depths to water grass and brush were no longer transpiring; the curves in figure 2 for grass and brush were then truncated at these depths for the respective sites. According to Blaney and Criddle (1962, p. 19), the $K$ value for alfalfa ranges from 0.80 to 0.90 . A constant of 0.85 was used for the range of depths to water at the study sites because of the capability of alfalfa roots to extend to great depth (Robinson, 1958, p. 60).

In the adaptation of the Rantz graph, the Cox and Havens graph, and the use of the $K$ value for alfalfa, it was assumed that the seasonal-growth coefficient $(\mathrm{K})$ could be used as the monthly growth coefficient $\left(\mathrm{K}_{\mathrm{m}}\right)$. Values of $\mathrm{K}_{\mathrm{m}}$ are determined by finding the mean depth to water each month on the vertical scale of figure 2 and reading the values of $\mathrm{K}_{\mathrm{m}}$ for respective vegetation types. 
The curves in figure 2 are based on the assumption of a dense growth of vegetation and must be adjusted to account for varying degrees of growth density. The density factors derived by Rantz (1968, p. D11) from a report by Blaney $(1954$, table

Density of growth Density factor dense 1.00 medium .85 light

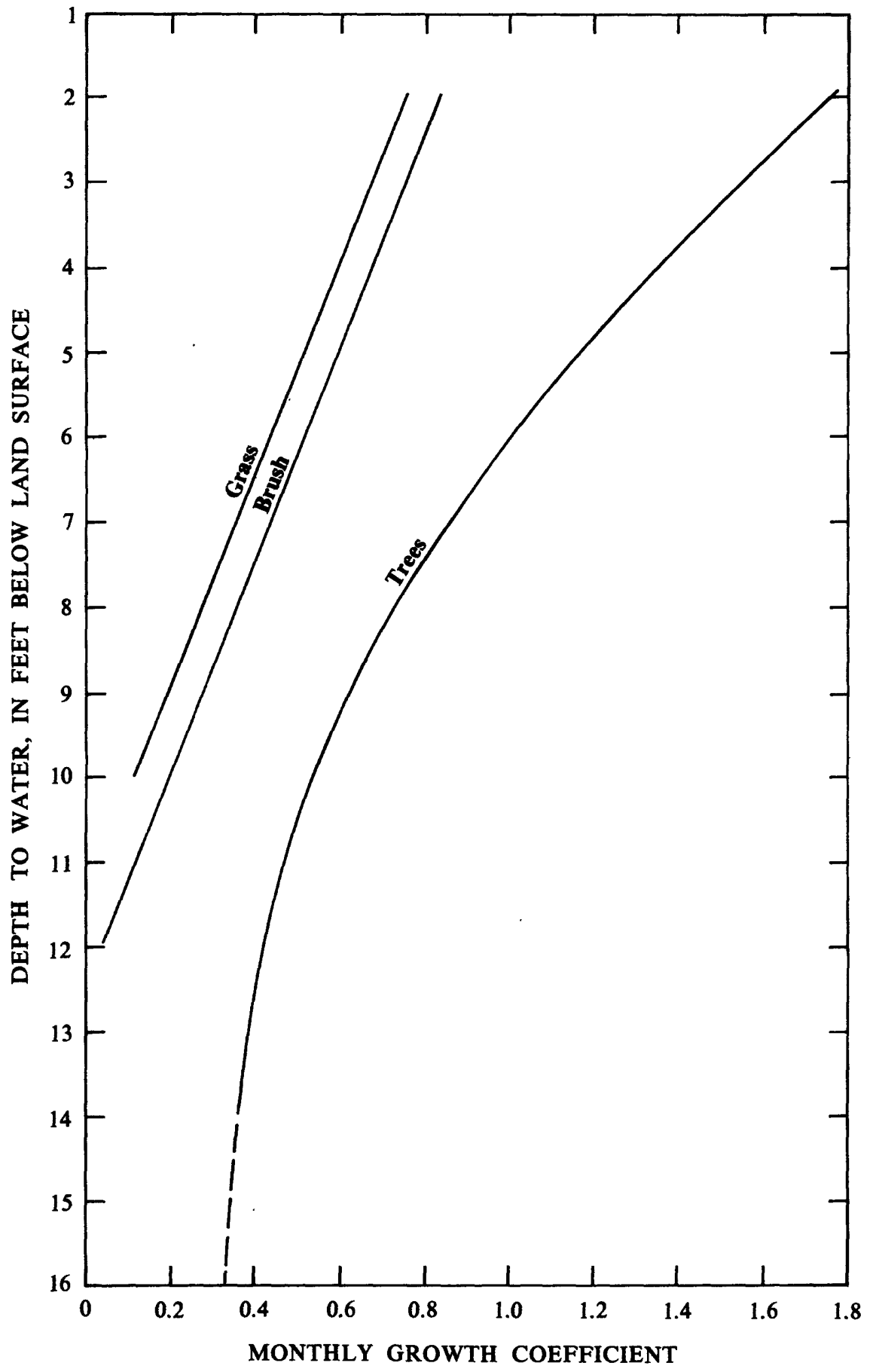

Modified from Rantz, 1968 and Cox and Havens, 1974.

Figure 2 Estimated values of monthly growth coefficients in relation to depth to water. 
To define dense, medium, and light growth in the study area, the weighted percentages of natural ground cover (table 1) were used arbitrarily in this report to develop the following growth ranges for the areas that did not contain cultivated acreage:

Grass-Range of percentage of ground covered is $70-80$ percent;

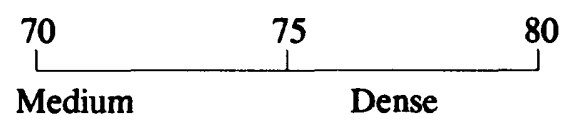

Brush-Range of percentage of ground covered is 10-35 percent; and

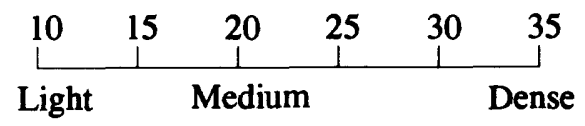

Trees-Range of percentage of ground covered is 0-35 percent.

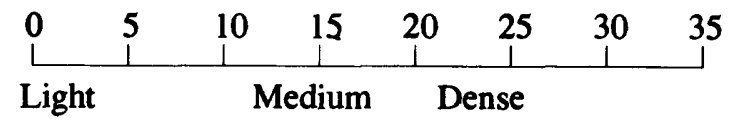

Cultivated acreage was considered as dense growth, and a density factor of 1.0 was applied. This resulted in a $\mathrm{K}_{\mathrm{m}}$ value for cultivated areas of 0.85 for the range of depths to water.

Using these ranges, density factors were chosen for the 12 sites (table 2). Again, only the weighted percentages of natural ground cover from table 1 were used.

After all adjustments were made, a single value for $\mathrm{K}_{\mathrm{m}}$ was determined monthly for each site using the following equation:

$$
\mathrm{K}_{\mathrm{c}}=\frac{\left(\mathrm{K}_{\mathrm{m} \text { grass }} \times d \mathrm{grass}_{\text {gras }} \times \mathrm{wf}_{\text {grass }}\right) / 100}{+\left(\mathrm{K}_{\mathrm{m} \text { brush }} \times d f_{\text {brush }} \times \mathrm{wf}_{\text {brush }}\right) / 100}
$$

where: $K_{c}=$ composite $K_{m}, K_{m}=K_{m}$ from figure 2 for the respective plant type, $d_{f}=$ density factor from table 2 for the respective plant type, and $\mathrm{wf}=$ weighting factor from table 1 for the respective plant type.

Table 2. Density factors used to compute corrected monthly growth coefficients.

\begin{tabular}{|c|c|c|c|c|}
\hline \multirow[b]{2}{*}{ Site } & \multicolumn{4}{|c|}{$\begin{array}{l}\text { Density factor } \\
\text { (df) }\end{array}$} \\
\hline & Grass & Brush & Trees & Alfalfa \\
\hline 1 & 1.0 & 1.0 & 0.70 & -- \\
\hline 2 & .85 & .85 & .70 & 1.0 \\
\hline 3 & 1.0 & .70 & 1.0 & 1.0 \\
\hline 4 & .85 & 1.0 & $\ldots$ & $\ldots$ \\
\hline $5^{1}(5 A)$ & .85 & .70 & 1.0 & -- \\
\hline $5^{1}(5 B)$ & 1.0 & .85 & .85 & -- \\
\hline 6 & .85 & .85 & -- & - \\
\hline 7 & 1.0 & .85 & .85 & -- \\
\hline 8 & .85 & 1.0 & .70 & -- \\
\hline 9 & 1.0 & .85 & .85 & 1.0 \\
\hline 10 & .85 & .85 & 1.0 & -- \\
\hline 11 & 1.0 & .85 & .70 & -- \\
\hline 12 & 1.0 & .70 & .70 & -- \\
\hline
\end{tabular}

1 Density factors were determined for two subareas within site 5 . 
Coefficient $p$ is the solar parameter in the Blaney-Criddle formula. It is the monthly percentage of daytime hours of the year. Values of $p$ were determined using finite-difference interpolation between latitudes $38^{\circ} \mathrm{N}$. and $44^{\circ} \mathrm{N}$. from meteorological tables (List, 1951).

\section{Determination of Temperature}

Because temperature records were not available for individual study sites, data from climatological stations near the sites were used to determine the temperature ( $t$ ) (table 3 ). The growing season listed in table 3 is the period between the last day of spring and the first day of fall in 1978 that a temperature of $28^{\circ} \mathrm{F}$ was recorded.

\section{SITE DESCRIPTION AND ANALYSIS}

\section{Primary Sites}

Most of the primary sites are located near surface-water gaging stations. Streamflow records were used to corroborate well data and to estimate data for missing periods of ground-water record.
Site 1 is located along East Fork Trail Creek near Quietus, Mont., in sec. 12, T. 9 S., R. 43 E. The observation well is located approximately 120 feet southeast of East Fork Trail Creek. The alluvium, consisting mainly of clay, fine sand, silt, and gravel, is $\mathbf{3 2}$ feet thick at the observation well and is underlain by the Tongue River Member of the Fort Union Formation of Paleocene age.

The plant community consists mainly of sagebrush and grass, with very few trees. The classification of vegetation by the Soil Conservation Service agrees closely with observations made from aerial photographș.

The depth to water, in feet below land surface, ranged from 4.1 on May 24 to 9.3 on October 13 at the observation well. Infrared photographs indicated that the sagebrush began showing stress from lack of water about July 13, when the depth to water was about 6 feet, and grass began showing stress about September 21, when the depth to water was about 9 feet. These depths were used as the limits at which evapotranspiration ceases for the respective vegetation. The water table at this site is closer to the land surface than the water table at most of the other sites, resulting in a greater seasonal rate of evapotranspiration relative to the other

Table 3. Average monthly temperatures for the 1978 growing season at sites studied.'

[Temperatures 1 isted only for months with well data available.

Temperature data from National Oceanic and Atmospheric

Administration, 1978a; 1978b]

\begin{tabular}{|c|c|c|c|c|c|c|c|c|c|c|}
\hline \multirow{2}{*}{ Site } & \multicolumn{2}{|c|}{1978} & \multirow{2}{*}{$\begin{array}{l}\text { Weather station used for } \\
\text { average temperature }\end{array}$} & \multicolumn{7}{|c|}{$\begin{array}{l}\text { Average monthly temperature (1978) } \\
\text { (degrees Fahrenheit) }\end{array}$} \\
\hline & growing & season & & April & May & June & July & Aug. & Sept. & Oct. \\
\hline \multicolumn{11}{|c|}{ Primary } \\
\hline 1 & $04-24$ to & $10-13$ & Otter 9 SSW, Mont. & 46.5 & 54.0 & 63.4 & 69.8 & 68.0 & 62.4 & 48.3 \\
\hline 2 & $04-24$ to & $10-13$ & Otter 9 SSW, Mont. & 46.5 & 54.0 & 63.4 & 69.8 & 68.0 & 62.4 & 48.3 \\
\hline 3 & $04-24$ to & $09-21$ & $\begin{array}{l}\text { Average of Oshoto } \\
15 \mathrm{NW} \text {, Wyo., and } \\
\text { Recluse } 14 \mathrm{NNW} \text {, Wyo. }\end{array}$ & 45.2 & 51.6 & 60.9 & 68.4 & 66.2 & 59.9 & 45.9 \\
\hline 4 & $04-22$ to & $10-06$ & Gillette 2 E, Wyo. & 44.7 & 50.6 & 61.4 & 68.6 & 66.8 & 61.7 & 48.8 \\
\hline 5 & $04-24$ to & $10-03$ & Dul1 Center, Wyo. & 47.0 & 52.2 & 64.6 & 71.9 & 67.8 & 63.0 & 49.8 \\
\hline \multicolumn{11}{|c|}{ Secondary } \\
\hline 6 & $04-24$ to & $10-03$ & Du11 Center, Wyo. & -- & - & 64.6 & 71.9 & 67.8 & 63.0 & 49.8 \\
\hline 7 & $04-22$ to & $10-03$ & Dead Horse Creek, Wyo. & -- & - & -- & 68.6 & 65.7 & 60.5 & 46.1 \\
\hline 8 & $04-24$ to & $10-03$ & Brandenberg, Mont. & 47.6 & - & -- & -- & -- & 60.1 & 47.2 \\
\hline & & & Colstrip, Mont. & -- & 55.0 & 63.8 & 69.2 & 67.5 & -- & - \\
\hline 9. & $04-24$ to & $10-05$ & Moorhead $9 \mathrm{NE}$, Mont. & -- & -- & 61.8 & -- & 67.0 & 61.6 & 48.5 \\
\hline & & & Biddle 8 SW, Mont. & -- & -- & -- & 69.2 & -- & -- & -- \\
\hline 10 & $04-24$ to & $09-21$ & $\begin{array}{l}\text { Average of Oshoto } \\
15 \mathrm{NW} \text {, Wyo. and }\end{array}$ & & & & & & & \\
\hline & & . & Recluse 14 NNW, Wyo. & -- & - & - & 68.4 & 66.2 & 59.9 & -- \\
\hline 11 & $04-22$ to & $10-06$ & Gillette $2 \mathrm{E}$, Wyo. & -- & - & 61.4 & 68.6 & 66.8 & 61.7 & 48.8 \\
\hline 12 & $04-22$ to & $10-06$ & Gillette 2 E, Wyo. & $\cdots$ & -- & 61.4 & 68.6 & 66.8 & 61.7 & 48.8 \\
\hline
\end{tabular}


sites. Monthly evapotranspiration rates ranged from 0 to 3.7 inches (table 4). The total evapotranspiration rate for the 1978 growing season was $\mathbf{1 2 . 4}$ inches.

\section{Site 2}

Site 2 is located in the Bear Creek drainage near Quietus, Mont., in sec. 34, T. 8 S., R. 45 E. The observation well is located approximately 330 feet west of Bear Creek and within 50 feet of an intermittent tributary to Bear Creek. The alluvium, consisting mainly of clay and gravel, is $\mathbf{4 2}$ feet thick at the well and is underlain by the Tongue River Member of the Fort Union Formation.

The plant community is mainly grass and sagebrush, with a few trees. In addition, approximately 30 percent of the area is cultivated. An aerial view of part of site 2 is shown in figure 3.

The depth to water in the well ranged from 6.8 feet below land surface on June 9 to 10.8 feet on October 5. Infrared photographs show that plant stress for both grass and brush occured between September 8 and 21. This could have been caused by subfreezing temperatures on September 20. The ground-water level during this period was 10.5 feet below land surface; this level was used as the depth limit of evapotranspiration for grass and brush. Evapotranspiration rates ranged from 0.92 (adjusted for part of a month) to 2.9 inches per month (table 5). The total evapotranspiration rate for the 1978 growing season was 12.3 inches.

\section{Site 3}

Site 3 is located along the Little Powder River in Wyoming near the Wyoming-Montana State line, in sec. 13, T. 57 N., R. $71 \mathrm{~W}$. The observation well is located approximately 30 feet west of the Little Powder River and 10 feet upstream from the U.S. Geological Survey streamflow-gaging station. The alluvium is 14 feet thick at the well, consists mainly of very fine grained sand and silt, and is underlain by the Tullock Member of the Fort Union Formation.

The plant community consists mainly of grass but also includes a relatively large concentration of willows and cottonwoods. Approximately 25 percent of the area is cultivated. An aerial view of part of site 3 is shown in figure 4 .

The estimated depth to water below land surface ranged from 5.8 feet in May to 10.4 feet in October at the observation well; depths to water had to be estimated because the recorder did not operate properly from May 9 to August 29. Infrared photographs indicated the grass became stressed between September 8 and 21, and the brush between September 21 and October 10. Subfreezing temperatures on September 20-21 possibly caused the grass to become dormant during the period; continued cold nighttime temperatures probably caused both grasses and brush to become dormant by early October. A depth limit for cessation of evapotranspiration of 10.0 feet was used for grass and 10.4 feet was used for brush. Evapotranspiration rates ranged from 1.5 (adjusted for part of a month) to 3.4 inches per month (table 6). The 1978 growing-season total was 14.1 inches.

Table 4. Computed evapotranspiration at site 1 .

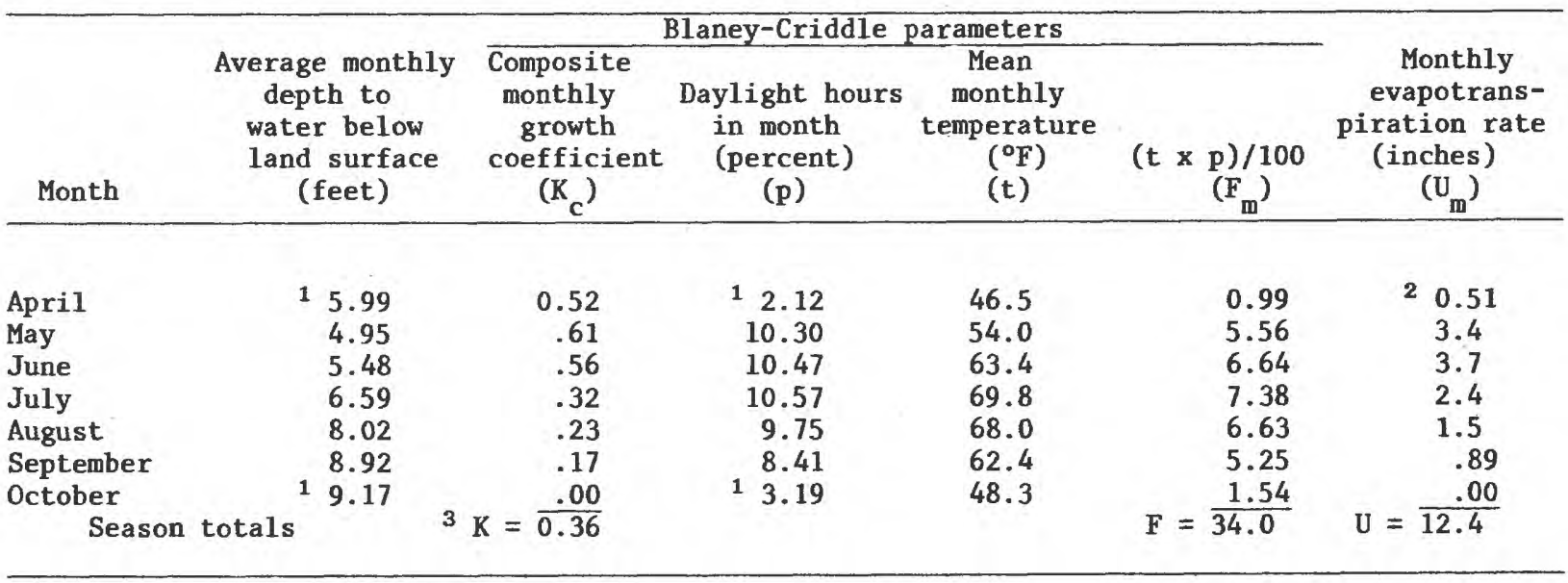

\footnotetext{
1 Adjusted because growing season did not include entire month.

2 Evapotranspiration for part of the month. Full-month value is 2.2.

$3 \mathrm{~K}=\mathrm{U} / \mathrm{F}$.
} 


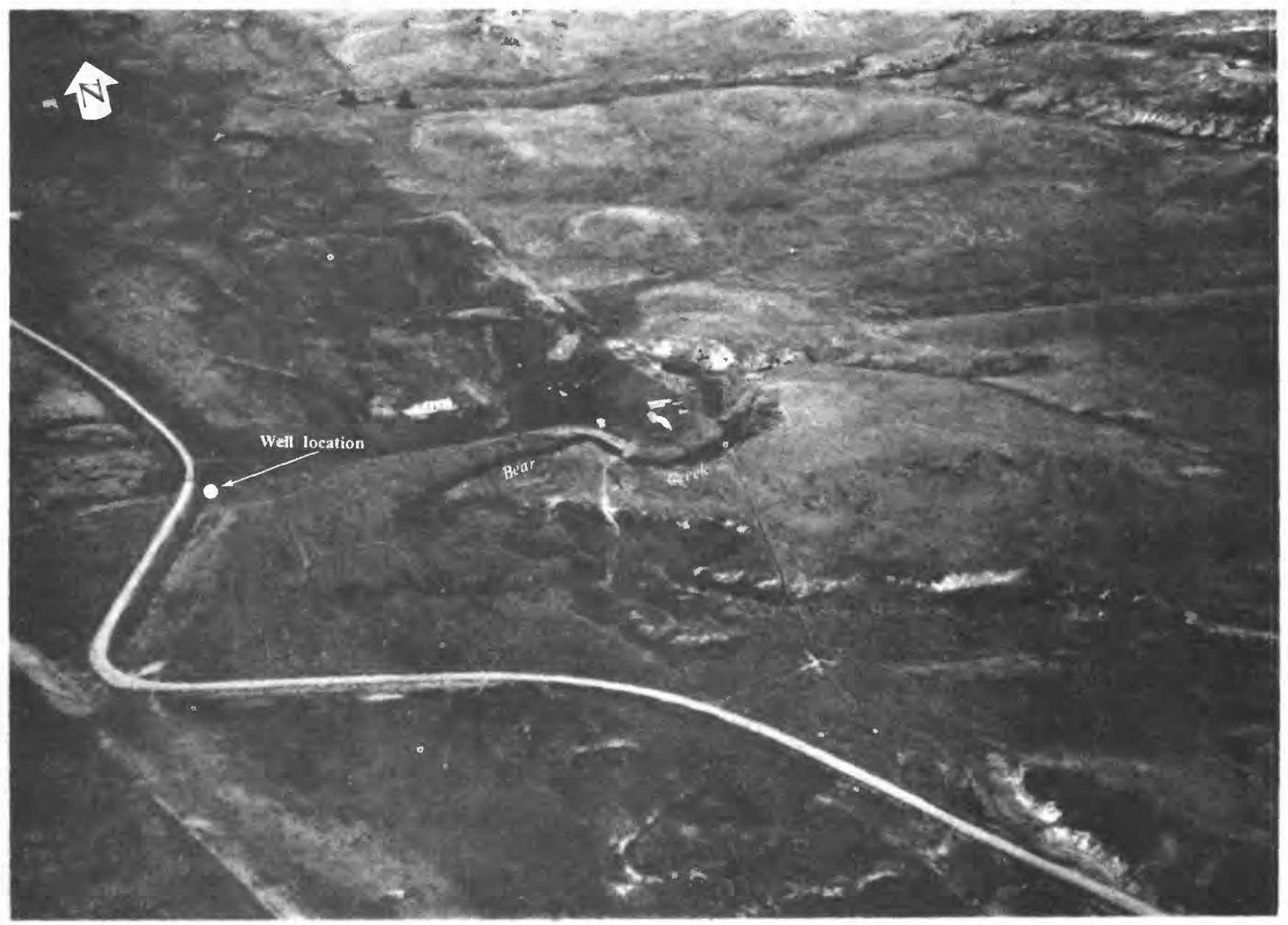

Figure 3 Aerial view of part of site 2.

Table 5. Computed evapotranspiration at site 2 .

\begin{tabular}{|c|c|c|c|c|c|c|}
\hline \multirow[b]{2}{*}{ Month } & \multirow[b]{2}{*}{$\begin{array}{c}\text { Average monthly } \\
\text { depth to } \\
\text { water below } \\
\text { land surface } \\
\text { (feet) }\end{array}$} & \multicolumn{4}{|c|}{ Blaney-Criddle parameters } & \multirow[b]{2}{*}{$\begin{array}{c}\text { Monthly } \\
\text { evapotrans- } \\
\text { piration rate } \\
(\text { inches }) \\
\left(\mathrm{U}_{\mathrm{m}}\right) \\
\end{array}$} \\
\hline & & $\begin{array}{l}\text { Composite } \\
\text { monthly } \\
\text { growth } \\
\text { coefficient } \\
\left(\mathrm{K}_{\mathrm{c}}\right)\end{array}$ & $\begin{array}{l}\text { Daylight hours } \\
\text { in month } \\
\text { (percent) } \\
\text { (p) }\end{array}$ & $\begin{array}{c}\text { Mean } \\
\text { monthly } \\
\text { temperature } \\
\left({ }^{\circ} \mathrm{F}\right) \\
(\mathrm{t}) \\
\end{array}$ & $\left(\begin{array}{c}(t \times x) / 100 \\
\left(F_{m}\right)\end{array}\right.$ & \\
\hline April & 19.57 & 0.36 & $\begin{array}{ll}12.12 \\
\end{array}$ & 46.5 & 0.99 & ${ }^{2} 0.35$ \\
\hline May & 9.19 & .38 & 10.30 & 54.0 & 5.56 & 2.1 \\
\hline June & 7.75 & .44 & 10.47 & 63.4 & 6.64 & 2.9 \\
\hline July & 8.92 & .39 & 10.57 & 69.8 & 7.38 & 2.9 \\
\hline August & 9.87 & .34 & 9.75 & 68.0 & 6.63 & 2.3 \\
\hline September & 10.5 & .26 & 8.41 & 62.4 & 5.25 & 1.4 \\
\hline October & 10.7 & & 13.19 & 48.3 & 1.54 & 3.40 \\
\hline Season & totals & $K=\overline{0.36}$ & & & $F=\overline{34.0}$ & $\mathrm{U}=\overline{12.3}$ \\
\hline
\end{tabular}

1 Adjusted because growing season did not include entire month.

2 Evapotranspiration for part of the month. Full-month value is 1.5 .

3 Evapotranspiration for part of the month. Full-month value is 0.92 .

$4 \mathrm{~K}=\mathrm{U} / \mathrm{F}$. 
Infrared photographs of this site also provided data for plotting the area of vegetation where evapotranspiration occurs along the Little Powder River (fig. 5). An area of $0.134 \mathrm{mi}^{2}$ was measured for a 1.57 -mile reach; this is equal to $0.085 \mathrm{mi}^{2}$ per mile of stream reach. Discharge per length of stream, in cubic feet per second per mile, was calculated by multiplying the rate of evapotranspiration by the area where evapotranspiration occurs ( $0.085 \mathrm{mi}^{2}$ per mile of reach). The net monthly discharge by evapotranspiration per mile of stream reach ranged from 0.11 to $0.26 \mathrm{ft}^{3} / \mathrm{s}$ at this site.

\section{Site 4}

Site 4 is located on the Belle Fourche River near Gillette, Wyo., in sec. 9, T. 46 N., R. 71 W. The observation well is located approximately 40 feet west of the Belle Fourche River and 10 feet upstream from the Geological Survey streamflowgaging station. The alluvium at the well is about 12 feet thick, consisting mainly of silt, clay, sand, and gravel, and is underlain by the Wasatch Formation of Eocene age.

The vegetation is mostly grass along the stream, with sagebrush on the banks and no trees. There is no cultivation at this site. An aerial view of part of site 4 is shown in figure 6.

Depth to water below land surface is shallow relative to the other sites, ranging from 3.8 feet on May 19 to 7.4 feet on October 6. Infrared photographs indicated the graphs became stressed between September 8 and 22, the brush became stressed after September 22. Minimum night temperatures were about freezing and may have caused the stress in September. Depths of water of 6.5 feet for grass and 7.5 feet for brush were used as the limits for cessation of evapotranspiration. Evapotranspiration rates were large relative to the other sites, due to the shallow water table, and ranged from 0.52 (adjusted for part of a month) to 3.6 inches monthly (table 7). The total evapotranspiration rate for the 1978 growing season was 14.9 inches.

The infrared photographs of the site indicate that the vegetation producing significant evapotranspiration is approximately 90 feet wide along the Belle Fourche River. The drainage area where evapotranspiration occurs for a 1.0 -mile reach is $0.017 \mathrm{mi}^{2}$. The range is net discharge from evapotranspiration was 0.01 to $0.05 \mathrm{ft}^{3} / \mathrm{s}$ per mile along this reach.

\section{Site 5}

Site 5 is located on the Cheyenne River near Dull Center, Wyo., in sections 19-21, T. 40 N., R.
$68 \mathrm{~W}$. Data were collected at two small subareas, $5 A$ and $5 B$, within site 5 because the subareas contained different vegetation densities. The two observation wells are located in subarea 5B, 100 feet and 375 feet south of the Cheyenne River and 20 feet downstream from the Geological Survey streamflow-gaging station. The alluvium at the observation wells is 12 to 20 feet thick, consisting of sand, silt, and some gravel, and is underlain by the Lebo Shale Member of the Fort Union Formation.

The plant community consists mainly of grass, some sagebrush, and a relatively large number of trees. There is no cultivation at these sites. An aerial view of subarea $5 \mathrm{~A}$ is shown in figure 7 and subarea $5 B$ in figure 8.

The water levels in the two wells in subarea 5B were averaged to obtain a mean depth to water below land surface; these water levels were assumed to be represetative of both subareas. The mean depth to water ranged from 5.8 feet on May 19 to 9.8 feet on October 3, which is about average in comparison to the other sites. Evapotranspirative discharge from grass ceased when the depth to water was 9.5 feet and from brush at 10 feet. The grass showed stress between September 8 and 22; brush and trees did not show stress until October 10, after subfreezing temperatures began. Evapotranspiration rates ranged from 0.84 (adjusted for part of a month) to 2.7 inches per month in subarea 5A (table 8) and 0.38 (adjusted for part of a month) to 2.1 inches per month in subarea 5B (table 9). Total evapotranspiration rate for subarea $5 \mathrm{~A}$ was 11.3 inches and for subarea 5B was 8.3 inches for the 1978 growing season.

The infrared photographs of these sites provided data for plotting the area of vegetation along the Cheyenne River where evapotranspiration occurs (fig. 9). Because subareas 5A and 5B fall within this plotted area, the average rates of evapotranspiration for the two subareas were used to calculate the discharge from the alluvial aquifer. An area of $0.487 \mathrm{mi}^{2}$ was measured for a 2.25 -mile reach; this is equal to $0.216 \mathrm{mi}^{2}$ per mile of stream reach. The net discharge by evapotranspiration per mile of stream reach ranged from 0.11 to $0.45 \mathrm{ft}^{3 / 3}$.

\section{Discussion of Primary Sites}

Evapotranspiration rates at the primary sites for the 1978 growing season ranged from 8.3 inches at site 5 to 14.9 inches at site 4 . The mean rate of evapotranspiration was 12.7 inches; the standard 


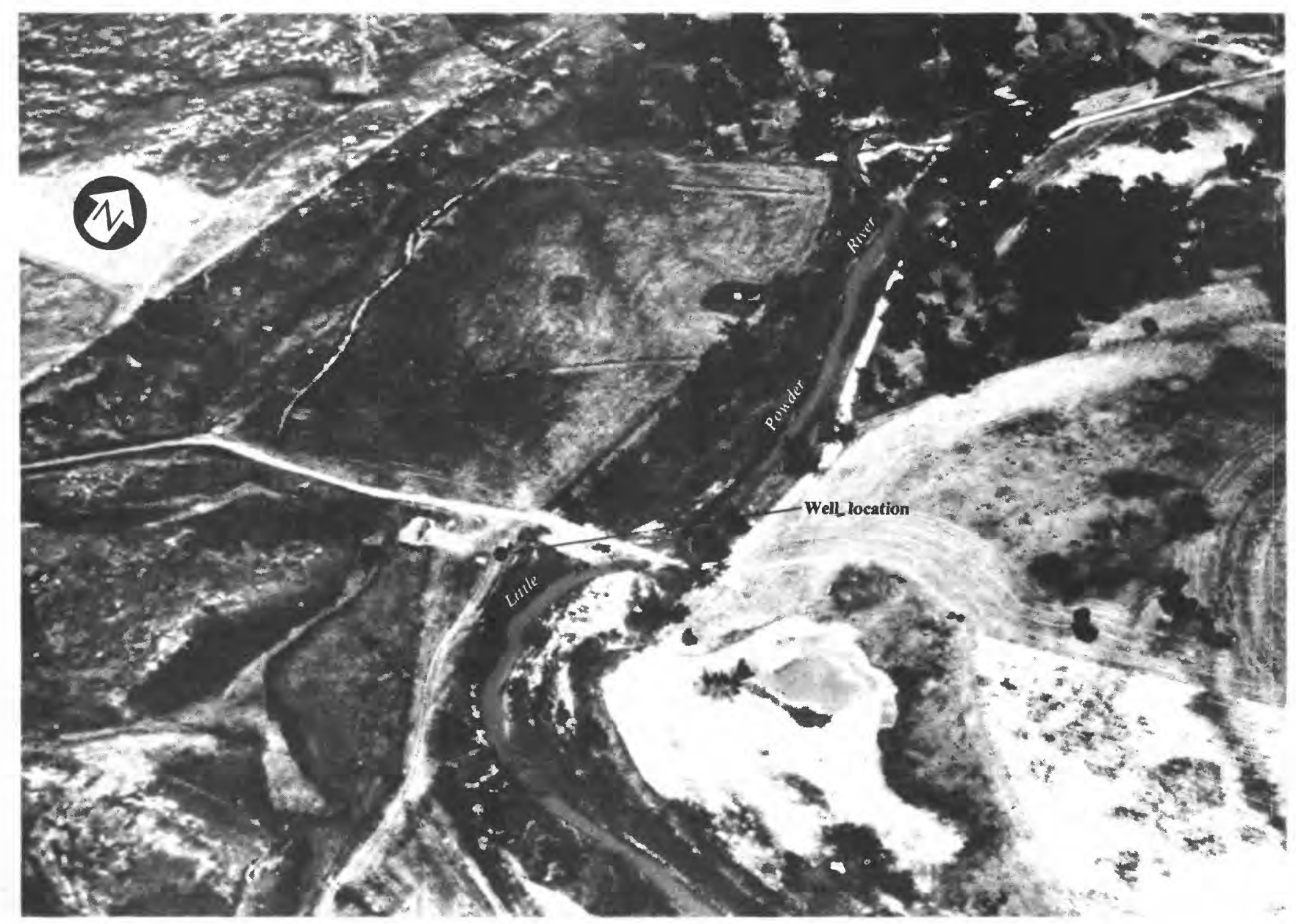

Figure 4 Aerial view of part of site 3.

Table 6. Computed evapotranspiration at site 3.

\begin{tabular}{|c|c|c|c|c|c|c|c|}
\hline \multirow[b]{2}{*}{ Month } & \multirow{2}{*}{\multicolumn{2}{|c|}{$\begin{array}{c}\text { Average monthly } \\
\text { depth to } \\
\text { water below } \\
\text { land surface } \\
\text { (feet) }\end{array}$}} & \multicolumn{4}{|c|}{ Blaney-Criddle parameters } & \multirow[b]{2}{*}{$\begin{array}{l}\text { Monthly } \\
\text { evapotrans- } \\
\text { piration rate } \\
\text { (inches) } \\
\left(\mathrm{U}_{\mathrm{m}}\right)\end{array}$} \\
\hline & & & $\begin{array}{l}\text { Composite } \\
\text { monthly } \\
\text { growth } \\
\text { coefficient } \\
\left(\mathrm{K}_{\mathrm{C}}\right) \\
\end{array}$ & $\begin{array}{l}\text { Daylight hours } \\
\text { in month } \\
\text { (percent) } \\
\text { (p) }\end{array}$ & $\begin{array}{c}\text { Mean } \\
\text { monthly } \\
\text { temperature } \\
\left({ }^{\circ} \mathrm{F}\right) \\
(\mathrm{t})\end{array}$ & $\begin{array}{c}(t \times x) / 100 \\
\left(F_{m}\right)\end{array}$ & \\
\hline April & & 16.05 & 0.65 & 12.11 & 45.2 & 0.95 & 20.62 \\
\hline May & & 6.73 & .60 & 10.28 & 51.6 & 5.30 & 3.2 \\
\hline June & & 7.74 & .53 & 10.44 & 60.9 & 6.36 & 3.4 \\
\hline July & & 8.88 & .45 & 10.55 & 68.4 & 7.22 & 3.2 \\
\hline August & & 9.48 & .41 & 9.73 & 66.2 & 6.44 & 2.6 \\
\hline September & $\mathbf{1}$ & 10.9 & .30 & 15.89 & 59.9 & 3.53 & $\begin{array}{lll}3 & 1.1\end{array}$ \\
\hline Season & totals & & $K=\widetilde{0.47}$ & & & $F=\overline{29.8}$ & $U=14.1$ \\
\hline
\end{tabular}

1 Adjusted because growing season did not include entire month.

2 Evapotranspiration for part of the month. Full-month value is 2.7.

3 Evapotranspiration for part of the month. Full-month value is 1.5 .

$4 \mathrm{~K}=\mathrm{U} / \mathrm{F}$. 
deviation was 1.97 inches, about 16 percent of the mean.

Discharge from the alluvial aquifers by evapotranspiration was calculated for a 1-mile reach at sites 3, 4, and 5. The average discharge for the 1978 growing season was $0.21 \mathrm{ft}^{3} / \mathrm{s}$ per mile of reach at site $3,0.03 \mathrm{ft}^{3} / \mathrm{s}$ per mile at site 4 , and $0.31 \mathrm{ft}^{3} / \mathrm{s}$ per mile at site 5 (table 10). Comparison of the mean discharge, growing-season evapotranspiration rates, and area per mile of reach in table 10 indicates that the net surface area has a greater effect on the discharge than the rate of evapotranspiration. Site 4 had the greatest rate of evapotranspiration but had the least average discharge per mile of the three sites where discharge was estimated. Site 5 had 34-percent less evapotranspiration than site 4 but had a tenfold increase in discharge as a result of the net area being about 10 times the net area at site 4 .

R. 71 W.
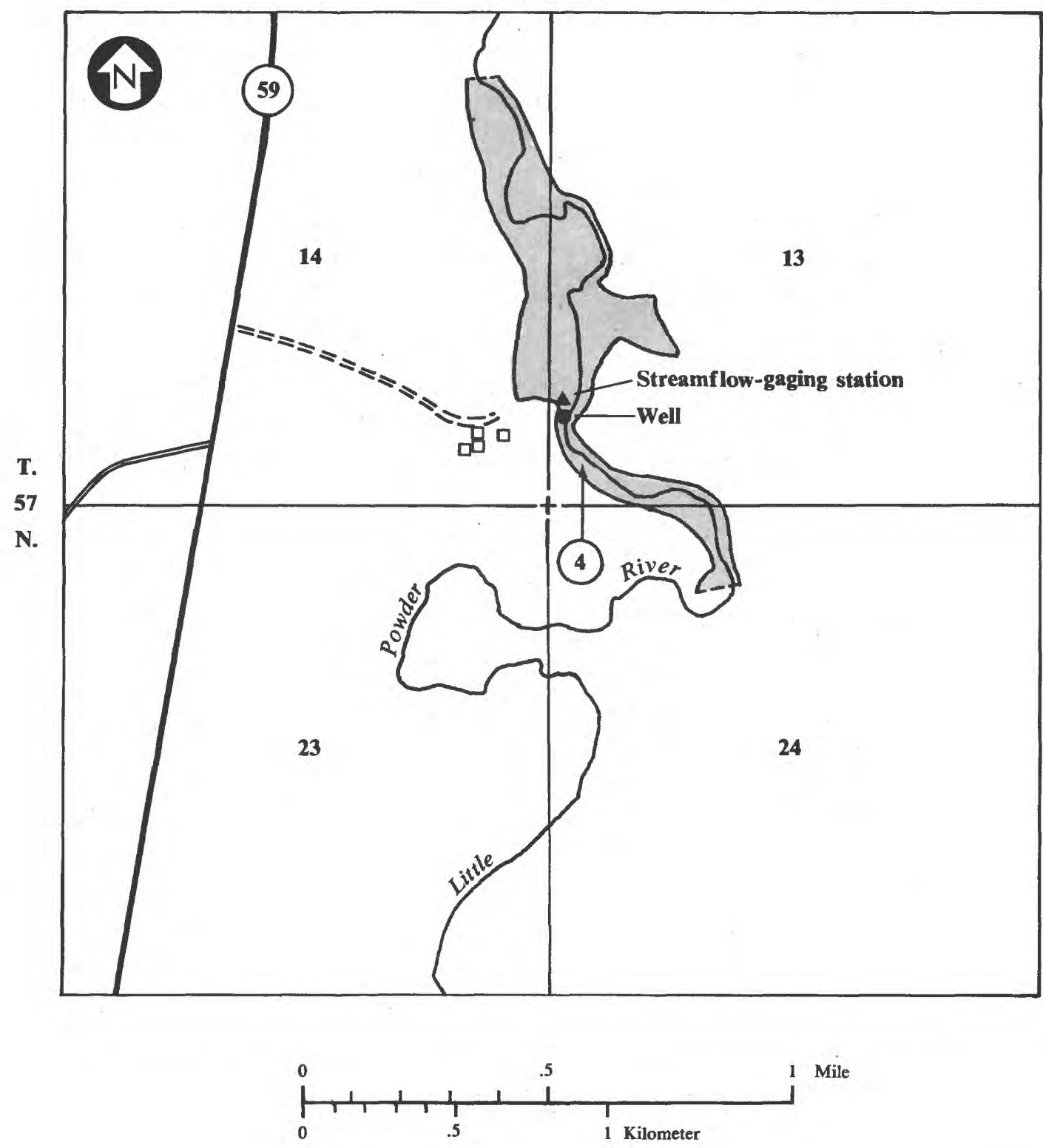

Figure 5 Area where evapotranspiration was estimated (patterned) at site 3. Arrow shows direction of photograph in figure 4. 


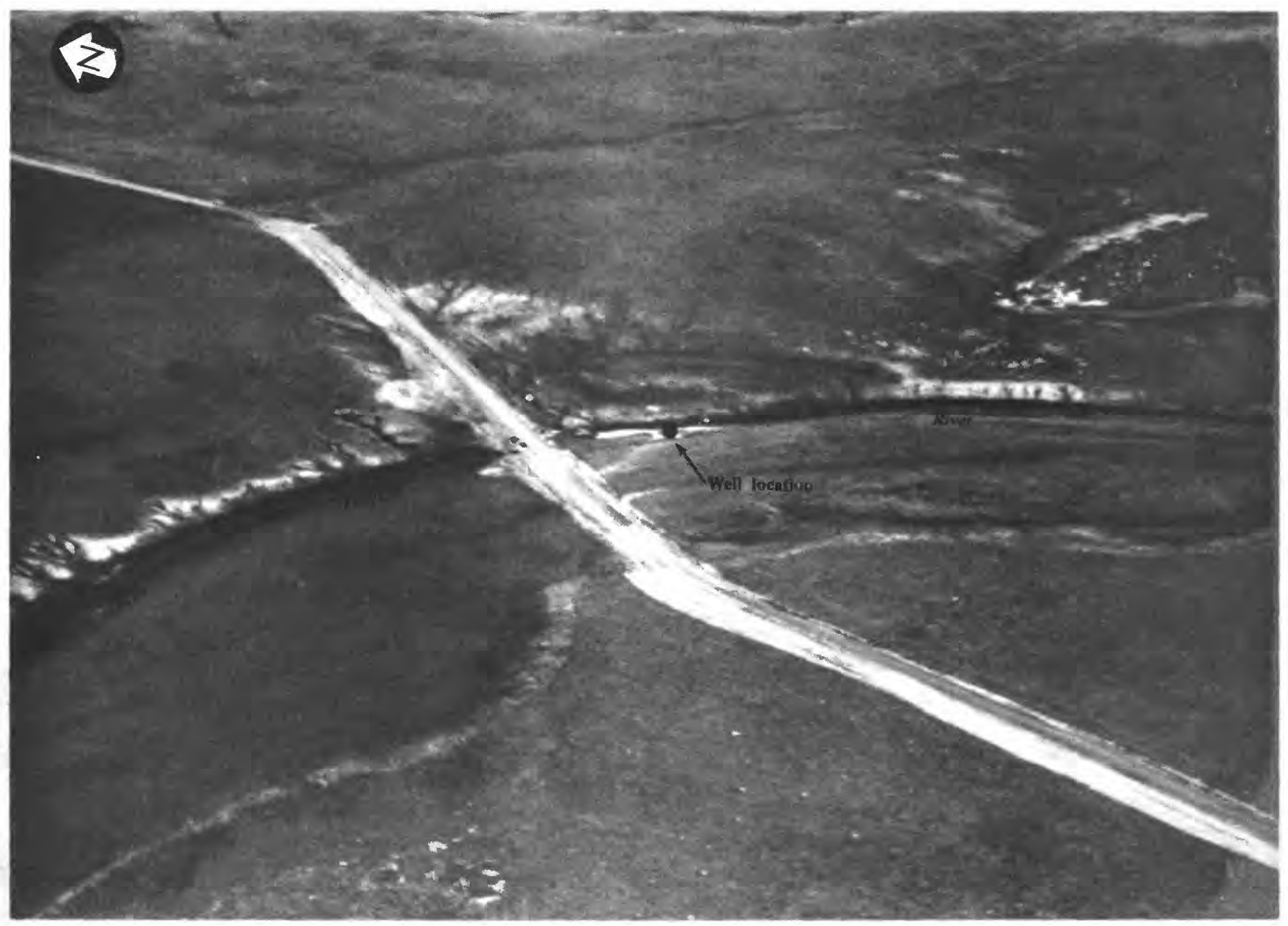

Figure 6 Aerial view of part of site 4.

Table 7. Computed evapotranspiration at site 4 .

\begin{tabular}{|c|c|c|c|c|c|c|c|}
\hline \multirow[b]{2}{*}{ Month } & \multirow{2}{*}{\multicolumn{2}{|c|}{$\begin{array}{c}\text { Average monthly } \\
\text { depth to } \\
\text { water below } \\
\text { land surface } \\
\text { (feet) }\end{array}$}} & \multicolumn{4}{|c|}{ Blaney-Criddle parameters } & \multirow[b]{2}{*}{$\begin{array}{l}\text { Monthly } \\
\text { evapotrans- } \\
\text { piration rate } \\
\text { (inches) } \\
\left(U_{\mathrm{m}}\right)\end{array}$} \\
\hline & & & $\begin{array}{l}\text { Composite } \\
\text { monthly } \\
\text { growth } \\
\text { coefficient } \\
\left(\mathrm{K}_{\mathrm{c}}\right) \\
\end{array}$ & $\begin{array}{l}\text { Daylight hours } \\
\text { in month } \\
\text { (percent) } \\
(\mathrm{p})\end{array}$ & $\begin{array}{c}\text { Mean } \\
\text { monthly } \\
\text { temperature } \\
\left({ }^{\circ} \mathrm{F}\right) \\
(\mathrm{t})\end{array}$ & $\left(\begin{array}{c}t \times x) / 100 \\
\left(F_{m}\right)\end{array}\right.$ & \\
\hline April & & 6.67 & 0.16 & 12.71 & 44.7 & 1.21 & 20.20 \\
\hline May & & 5.59 & .47 & 10.22 & 50.6 & 5.17 & 2.4 \\
\hline June & & 4.92 & .53 & 10.39 & 61.4 & 6.38 & 3.4 \\
\hline July & & 5.26 & .50 & 10.49 & 68.6 & 7.20 & 3.6 \\
\hline August & & 5.63 & .47 & 9.70 & 66.8 & 6.48 & 3.1 \\
\hline September & & 6.45 & .41 & 8.41 & 61.7 & 5.19 & 2.1 \\
\hline October & & 7.44 & .14 & 11.48 & 48.8 & .72 & 3.10 \\
\hline Season & totals & 4 & $K=\overline{0.46}$ & & & $F=\overline{32.4}$ & $U=\overline{14.9}$ \\
\hline
\end{tabular}

1 Adjusted because growing season did not include entire month.

2 Evapotranspiration for part of the month. Full-month value is 0.65 .

3 Evapotranspiration for part of the month. Full-month value is 0.52 .

$4 \mathrm{~K}=\mathrm{U} / \mathrm{F}$. 


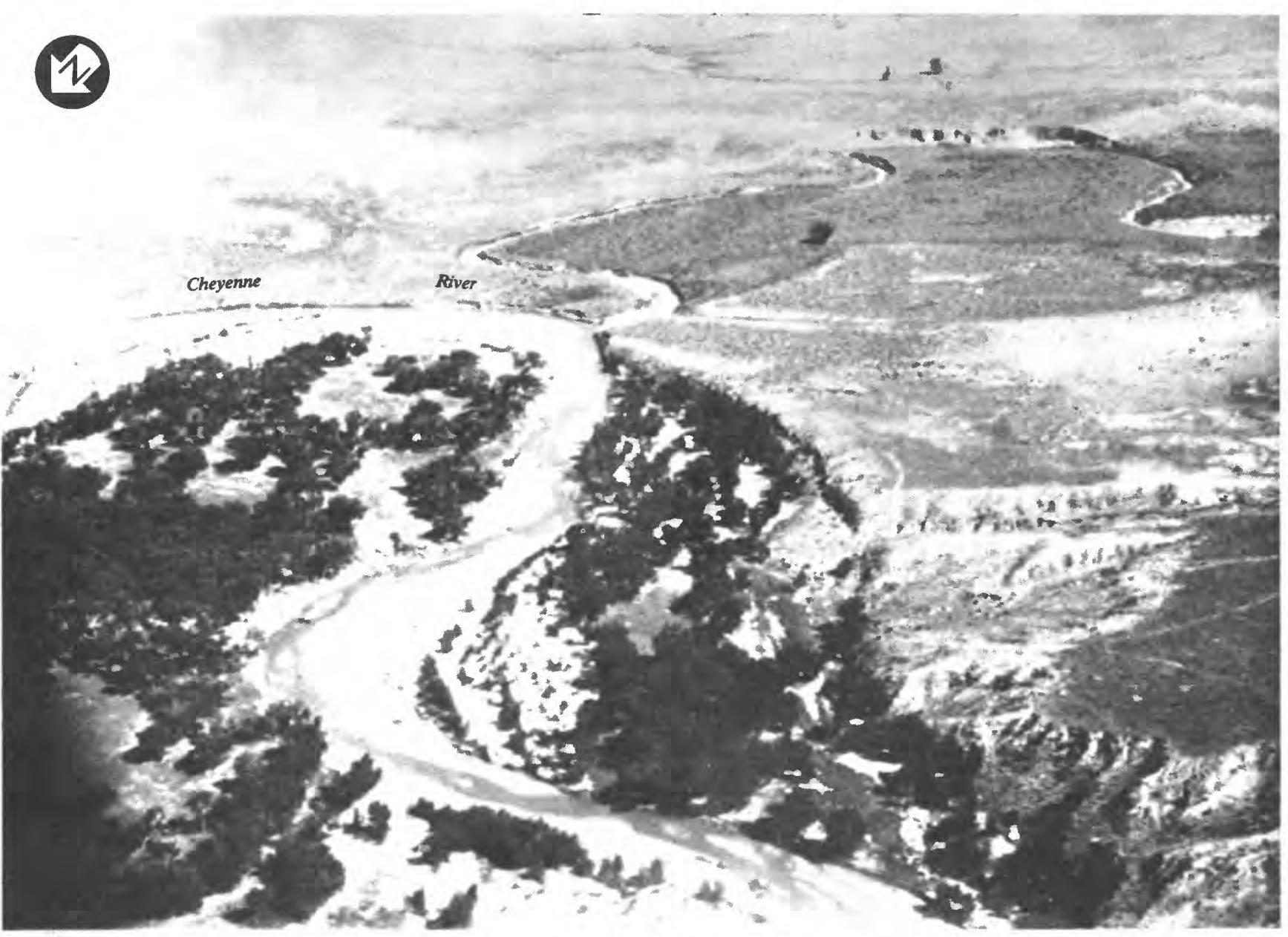

Figure 7 Aerial view of subarea 5A.

Table 8. Computed evapotranspiration at subarea 5A.

\begin{tabular}{|c|c|c|c|c|c|c|c|}
\hline \multirow[b]{2}{*}{ Month } & \multirow{2}{*}{\multicolumn{2}{|c|}{$\begin{array}{c}\text { Average monthly } \\
\text { depth to } \\
\text { water below } \\
\text { land surface } \\
\text { (feet) }\end{array}$}} & \multicolumn{4}{|c|}{ Blaney-Criddle parameters } & \multirow[b]{2}{*}{$\begin{array}{c}\text { Monthly } \\
\text { evapotrans- } \\
\text { piration rate } \\
\text { (inches) } \\
\left(\mathrm{U}_{\mathrm{m}}\right)\end{array}$} \\
\hline & & & $\begin{array}{l}\text { Composite } \\
\text { monthly } \\
\text { growth } \\
\text { coefficient } \\
\left(\mathrm{K}_{\mathrm{C}}\right)\end{array}$ & $\begin{array}{c}\text { Daylight hours } \\
\text { in month } \\
\text { (percent) } \\
(\mathrm{p})\end{array}$ & $\begin{array}{c}\text { Mean } \\
\text { monthly } \\
\text { temperature } \\
\left({ }^{\circ} \mathrm{F}\right) \\
(\mathrm{t})\end{array}$ & $\begin{array}{c}(t \times p) / 100 \\
\left(F_{m}\right)\end{array}$ & \\
\hline April & & 9.24 & 0.34 & 12.10 & 47.0 & 0.99 & 20.33 \\
\hline May & & 8.25 & .43 & 10.18 & 52.2 & 5.31 & 2.3 \\
\hline June & & 8.63 & .39 & 10.35 & 64.6 & 6.69 & 2.6 \\
\hline July & & 9.04 & .35 & 10.45 & 71.9 & 7.51 & 2.7 \\
\hline August & & 9.28 & .33 & 9.68 & 67.8 & 6.56 & 2.2 \\
\hline September & & 9.65 & .22 & 8.41 & 63.0 & 5.30 & 1.1 \\
\hline October & 1 & 9.66 & .22 & $1 \quad .74$ & 49.8 & .37 & 3.08 \\
\hline Seasor & totals & 4 & $K=\overline{0.35}$ & & & $F=\overline{32.7}$ & $U=\overline{11.3}$ \\
\hline
\end{tabular}

\footnotetext{
1 Adjusted because growing season did not include entire month.

2 Evapotranspiration for part of the month. Full-month value is 1.4.

3 Evapotranspiration for part of the month. Full-month value is 0.84 .

$4 \mathrm{~K}=\mathrm{U} / \mathrm{F}$.
} 


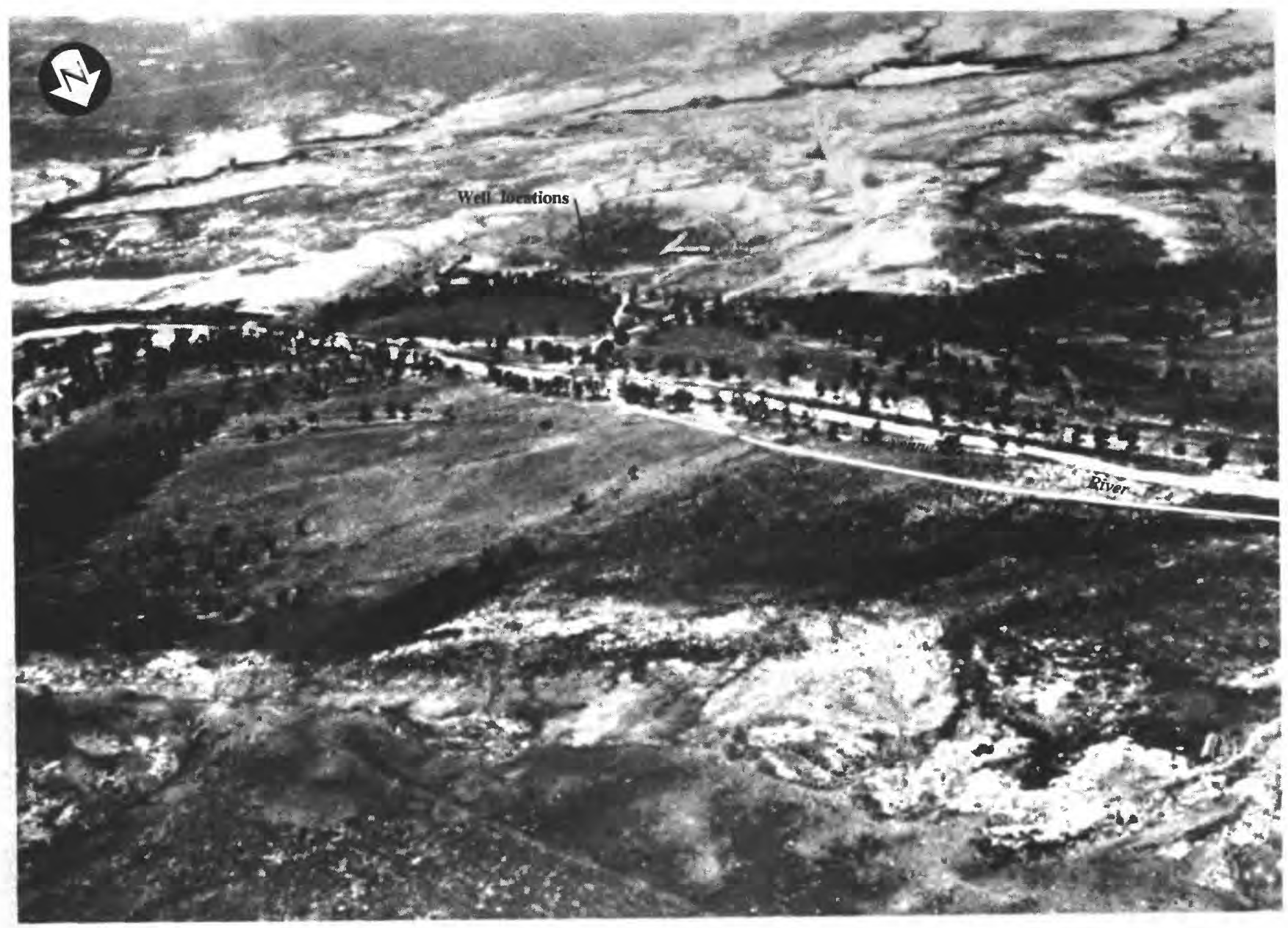

Figure 8 Aerial view of mbarea 5.

Table 9. Computed evapotranspiration at subarea $5 B$.

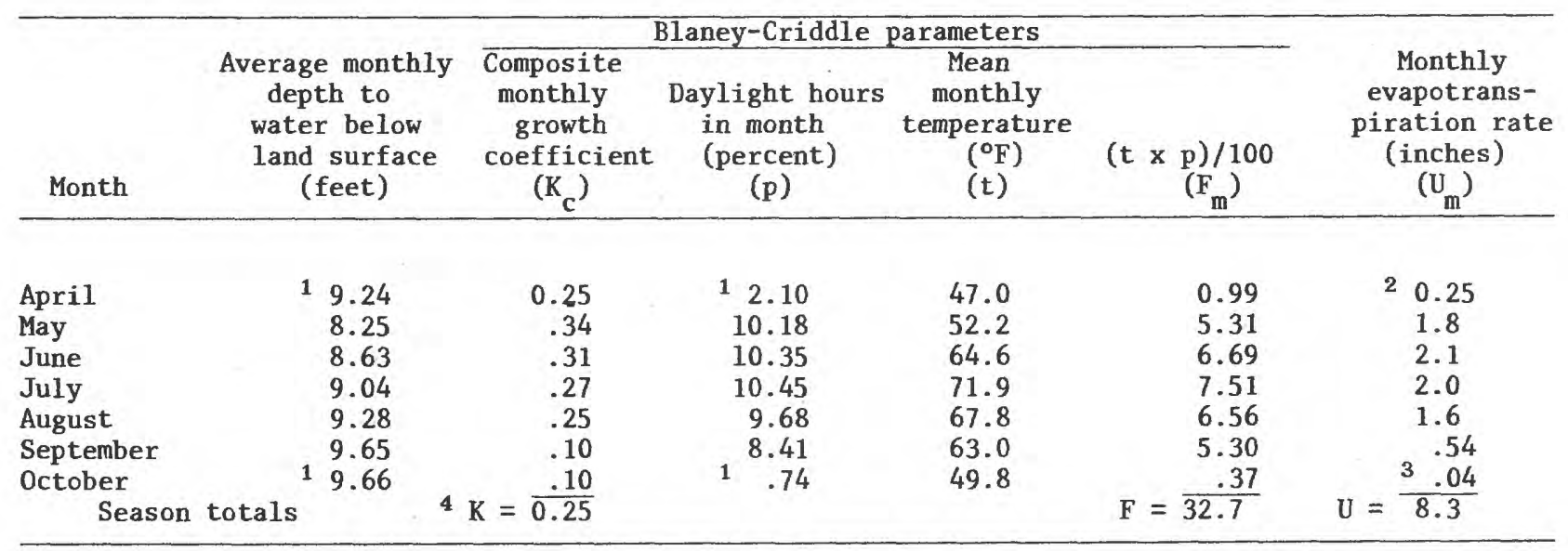

1 Adjusted because growing season did not include entire month.

2 Evapotranspiration for part of the month. Full-month value is 1.1 .

3 Evapotranspiration for part of the month. Full-month value is 0.38 .

$4 \mathrm{~K}=\mathrm{U} / \mathrm{F}$. 


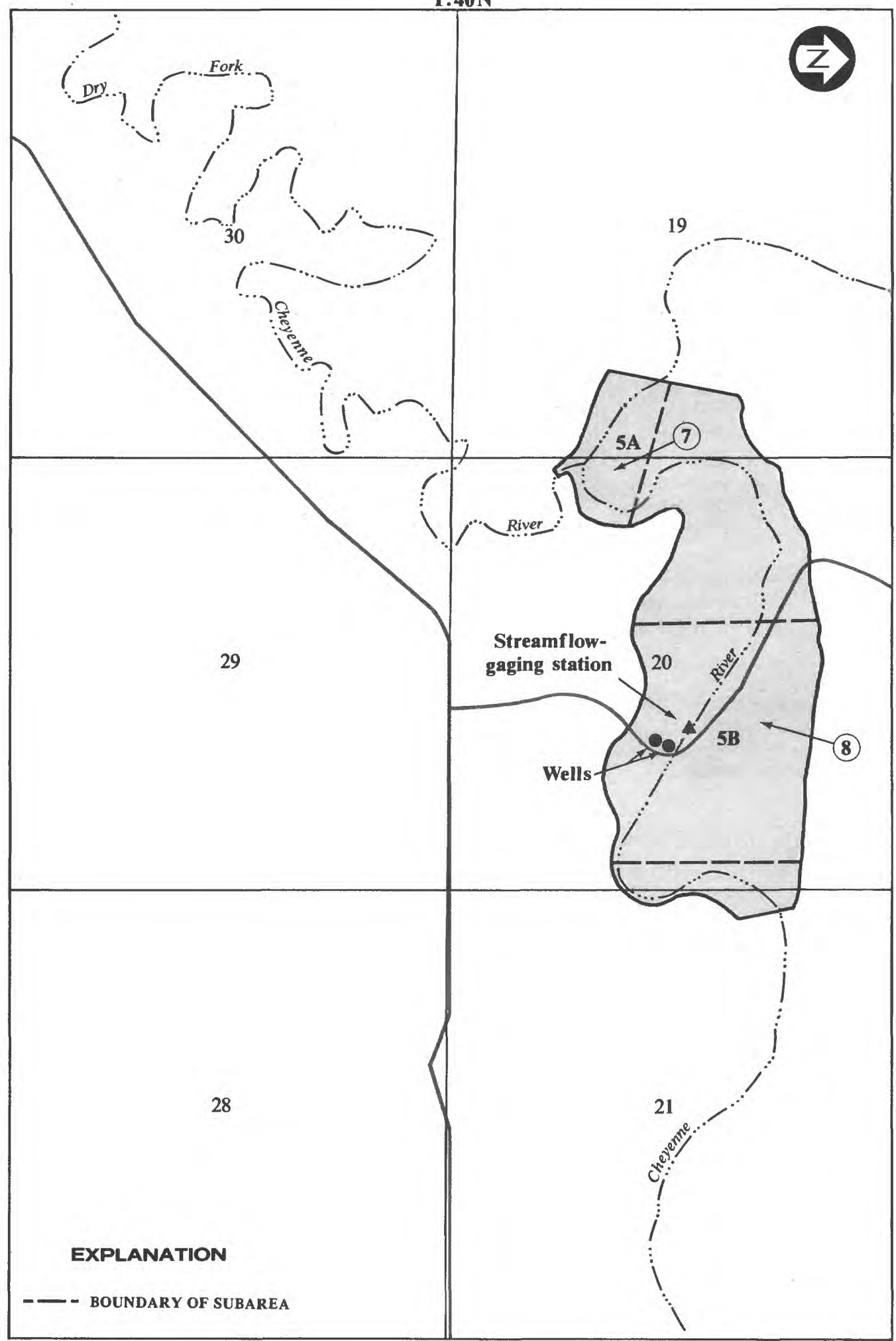

R. 68 W.

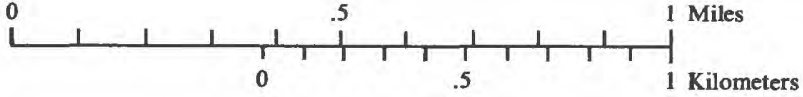

Figure 9 Area where evapotranspiration was estimated (patterned) at site 5. Arrows show direction of photographs of subareas $5 \mathrm{~A}$ and $5 \mathrm{~B}$ in figures 7 and 8. 
Table 10 Evapotranspirative discharge from alluvial aquifers at Sites 3,4 , and 5 .

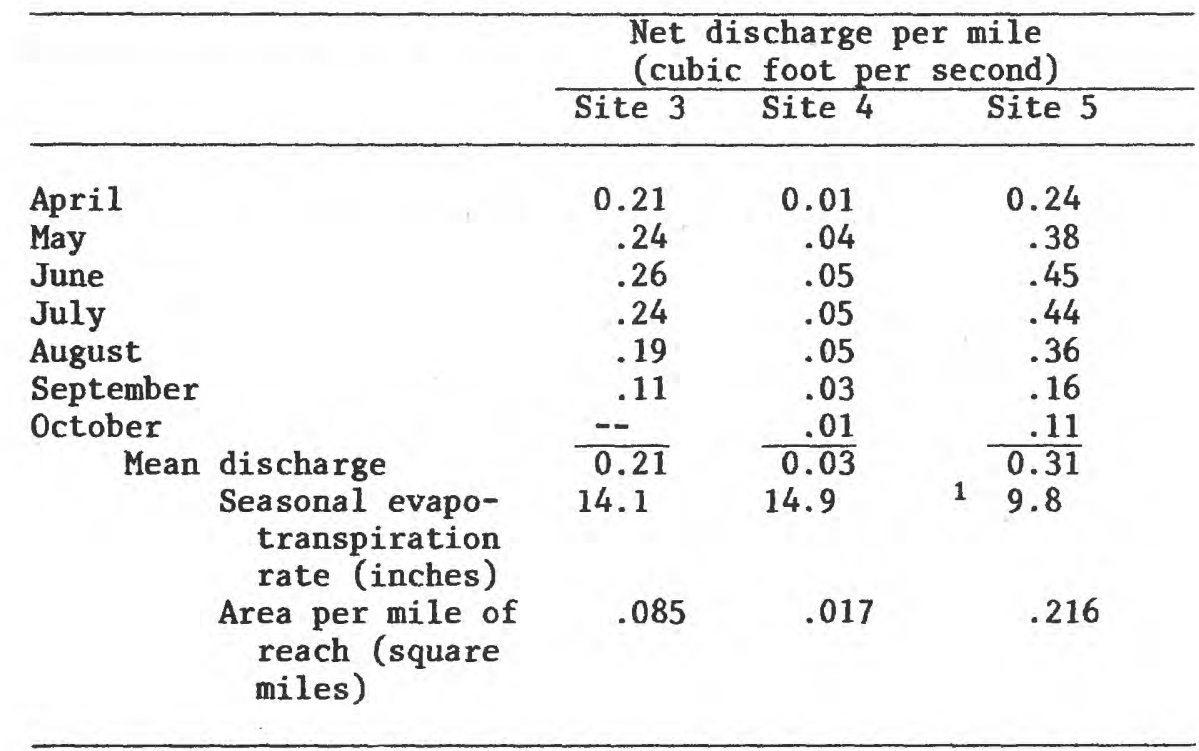

1 Average of evapotranspiration rates of subareas $5 \mathrm{~A}$ and $5 \mathrm{~B}$.

\section{Secondary Sites}

The well records of the remaining seven sites $(6$, $7,8,9,10,11$, and 12) consist of periodic, usually monthly or less frequent, measurements of groundwater levels. These sites are called secondary sites. The well records at all but site 8 did not include the entire growing season. Evapotransipration values were calculated only for the months for which water-level data were available. The seasonal total was calculated for site 8 only. Infrared photographs of the secondary sites also were used to determine when and at what ground-water depth the evapotranspirative process ceased for the respective vegetation group due to a lack of water or cold weather.

\section{Site 6}

Site 6 is located on the Dry Fork Cheyenne River near Bill, Wyo., in sec. 31, T. 38 N., R. 74 W. Ground-water-level data at this site were provided by monthly water-level measurements in an observation well located approximately 10 feet north of the Dry Fork Cheyenne River. The thickness of the alluvium is not known, but the alluvium consists mainly of sand and is underlain by the Wasatch Formation. Vegetation consists mostly of grass in the stream channel and sagebrush and a few trees along the banks.
The well data consist of six measurements of depth to water made between May 31 and October 2 , 1978. There is good correlation between the water level (stage) of the river and the water level in the well. Surface-water records are available for this site and give a range of river stages resulting in an approximate range of water levels in the well. Water levels in the observation well between measurements can be estimated from the six depthto-water measurements and surface-water records. Computed evapotranspiration rates ranged from 1.8 (adjusted for part of a month) to 3.8 inches per month (table 11).

\section{Site 7}

Site 7 is located on Dead Horse Creek near Buffalo, Wyo., in sec. 15, T. 49 N., R. 77 W. Ground-water-level data were provided by monthly water-level measurements in an observation well located 150 feet north of Dead Horse Creek. Additional data for October were provided by a waterlevel recorder on the observation well. The alluvium at the observation well is 20 feet thick, consisting mainly of silt and gravel, and is underlain by the Wasatch Formation. The vegetation at this site consists mainly of grass, with some sagebrush and trees. 
Table 11. Computed evapotranspiration at Site 6.

[Evapotranspiraton values were calculated only for the months for which water-level data were available. Depth to water for cessation of evapotranspiration from grass and brush was 4 feet]

\begin{tabular}{|c|c|c|c|c|c|c|}
\hline \multirow[b]{2}{*}{ Month } & \multirow[b]{2}{*}{$\begin{array}{c}\text { Average monthly } \\
\text { depth to } \\
\text { water below } \\
\text { land surface } \\
\text { (feet) }\end{array}$} & \multicolumn{4}{|c|}{ Blaney-Criddle parameters } & \multirow[b]{2}{*}{$\begin{array}{l}\text { Monthly } \\
\text { evapotrans- } \\
\text { piration rate } \\
\text { (inches) } \\
\left(\mathrm{U}_{\mathrm{m}}\right)\end{array}$} \\
\hline & & $\begin{array}{l}\text { Composite } \\
\text { monthly } \\
\text { growth } \\
\text { coefficient } \\
\left(\mathrm{K}_{\mathrm{c}}\right) \\
\end{array}$ & $\begin{array}{l}\text { Daylight hours } \\
\text { in month } \\
\text { (percent) } \\
\text { (p) }\end{array}$ & $\begin{array}{c}\text { Mean } \\
\text { monthly } \\
\text { temperature } \\
\left({ }^{\circ} \mathrm{F}\right) \\
(\mathrm{t})\end{array}$ & $\left(\begin{array}{c}t \times p) / 100 \\
\left(F_{m}\right)\end{array}\right.$ & \\
\hline June & 2.99 & 0.53 & 10.34 & 64.6 & 6.68 & 3.6 \\
\hline July & 3.49 & .50 & 10.43 & 71.9 & 7.50 & 3.8 \\
\hline August & 3.79 & .49 & 9.67 & 67.8 & 6.56 & 3.2 \\
\hline September & 3.90 & .48 & 8.41 & 63.0 & 5.30 & 2.5 \\
\hline October & 13.90 & .48 & .74 & 49.8 & .37 & 2.18 \\
\hline
\end{tabular}

1 Adjusted because growing season did not include entire month.

2 Evapotranspiration for part of the month. Full-month value is 1.8 .

Well data consist of six measurements of depth to water made between July 26 and November 24, 1978 , and recorder data for October. There is good correlation between surface-water records and water levels in the observation well; water levels in the observation well can be estimated from this correlation and the six measurements of depth to water. Evapotranspiration rates from July to October 1978 ranged from 0.67 (adjusted for part of a month) to 1.4 inches per month (table 12).

\section{Site 8}

Site 8 is located along the Tongue River near Brandenberg, Mont., in sec. 6, T. 1 N., R. 45 E. Ground-water-level data at this site were provided by periodic water-level measurements in an observation well located approximately 200 feet northwest of the Tongue River. The alluvium at the observation well is $\mathbf{2 7}$ feet thick, consisting mainly of sand, gravel, and silty shale, and is underlain by the Lebo Shale Member of the Fort Union Formation. The vegetation at this site consists mainly of grass, with some sagebrush and trees along the banks.

The well data consist of six irregularly spaced measurements of ground-water levels. The estimated ground-water levels are less reliable at this site than at most of the other sites because of the more widely spaced water-level measurements. Estimates of evapotranspiration rates ranged from 0.07 (adjusted for part of a month) to 2.9 inches per month (table 13). The well record included the entire 1978 growing season. The evapotranspiration rate totaled 9.7 inches.

\section{Site 9}

Site 9 is located along the Powder River near Moorhead, Mont., in sec. 8, T. 9 S., R. 48 E. Only three water-level measurements were made at this site in an observation well located approximately 400 feet west of the Powder River. The well at this site may extend below the alluvium into bedrock (M. E. Lowry, U.S. Geological Survey, oral commun. Oct. 1979), and water-level measurements may not indicate the true depth to water in the alluvium. A $\log$ for the observation well is not available, so the composition and thickness of the alluvium are not known. The alluvium is underlain by the Tongue River Member of the Fort Union Formation. The natural vegetation is mostly grass, with a few trees. Approximately 50 percent of the area is cultivated.

Only three measurements of water levels in the observation well were made between May 22 and December 14, 1978, making estimates of monthly average water levels very unreliable. Estimates of evapotranspiration rates ranged from 1.6 (adjusted for part of a month) to 3.2 inches per month (table 14).

\section{Site 10}

Site 10 is located along Elk Creek near Weston, Wyo., in sec. 30, T. 56 N., R. 71 W. The groundwater-level data at this site were provided by averaging observations of water levels in two wells located approximately 20 and 60 feet south of Elk Creek. 
The alluvium is 23 feet thick, consisting of medium to fine gravel and sand underlain by the Lebo Shale Member of the Fort Union Formation. Grass dominates the plant community, which also includes some sagebrush and a larger number of trees than most of the other sites.

Well records consist of four measurements of water levels made at two wells between July 19 and
November 14, 1978. The water levels for the two wells were averaged and used to estimate the ground-water level used in determining the crop coefficient $\mathbf{k}$. The mean ground-water levels were not considered reliable because so few measurements were made. Estimates of evapotranspiration rates ranged from 0.55 (adjusted for part of a month) to 1.8 inches per month (table 15).

Table 12. Computed evapotranspiration at Site 7.

[Evapotranspiration values were calculated only for the months when water-level data were available. Depth to water for cessation of evapotranspiration from grass and brush was 10 feet]

\begin{tabular}{|c|c|c|c|c|c|c|}
\hline \multirow[b]{2}{*}{ Month } & \multirow[b]{2}{*}{$\begin{array}{c}\text { Average monthly } \\
\text { depth to } \\
\text { water below } \\
\text { land surface } \\
\text { (feet) }\end{array}$} & \multicolumn{4}{|c|}{ Blaney-Criddle parameters } & \multirow[b]{2}{*}{$\begin{array}{l}\text { Monthly } \\
\text { evapotrans- } \\
\text { piration rate } \\
\text { (inches) } \\
\left(U_{m}\right)\end{array}$} \\
\hline & & $\begin{array}{l}\text { Composite } \\
\text { monthly } \\
\text { growth } \\
\text { coefficient } \\
\left(\mathrm{K}_{\mathrm{C}}\right)\end{array}$ & $\begin{array}{l}\text { Daylight hours } \\
\text { in month } \\
\text { (percent) } \\
\text { (p) }\end{array}$ & $\begin{array}{c}\text { Mean } \\
\text { monthly } \\
\text { temperature } \\
\left({ }^{\circ} \mathrm{F}\right) \\
(\mathrm{t})\end{array}$ & $\left(\begin{array}{c}(t \times p) / 100 \\
\left(F_{m}\right)\end{array}\right.$ & \\
\hline $\begin{array}{l}\text { July } \\
\text { August } \\
\text { September } \\
\text { October }\end{array}$ & $\begin{array}{r}9.73 \\
9.90 \\
9.96 \\
19.82\end{array}$ & $\begin{array}{r}0.20 \\
.18 \\
.18 \\
.19\end{array}$ & $\begin{array}{r}10.51 \\
9.71 \\
8.41 \\
1 \quad .74\end{array}$ & $\begin{array}{l}68.6 \\
65.7 \\
60.5 \\
46.1\end{array}$ & $\begin{array}{r}7.21 \\
6.38 \\
5.09 \\
.34\end{array}$ & $\begin{array}{r}1.4 \\
1.2 \\
. .91 \\
2.06\end{array}$ \\
\hline
\end{tabular}

1 Adjusted because growing season did not include entire month.

2 Evapotranspiration for part of the month. Full-month value is 0.67 .

Table 13. Computed evapotranspiration at Site 8.

[Depth to water for cessation of evapotranspiration from grass and brush was 9 feet]

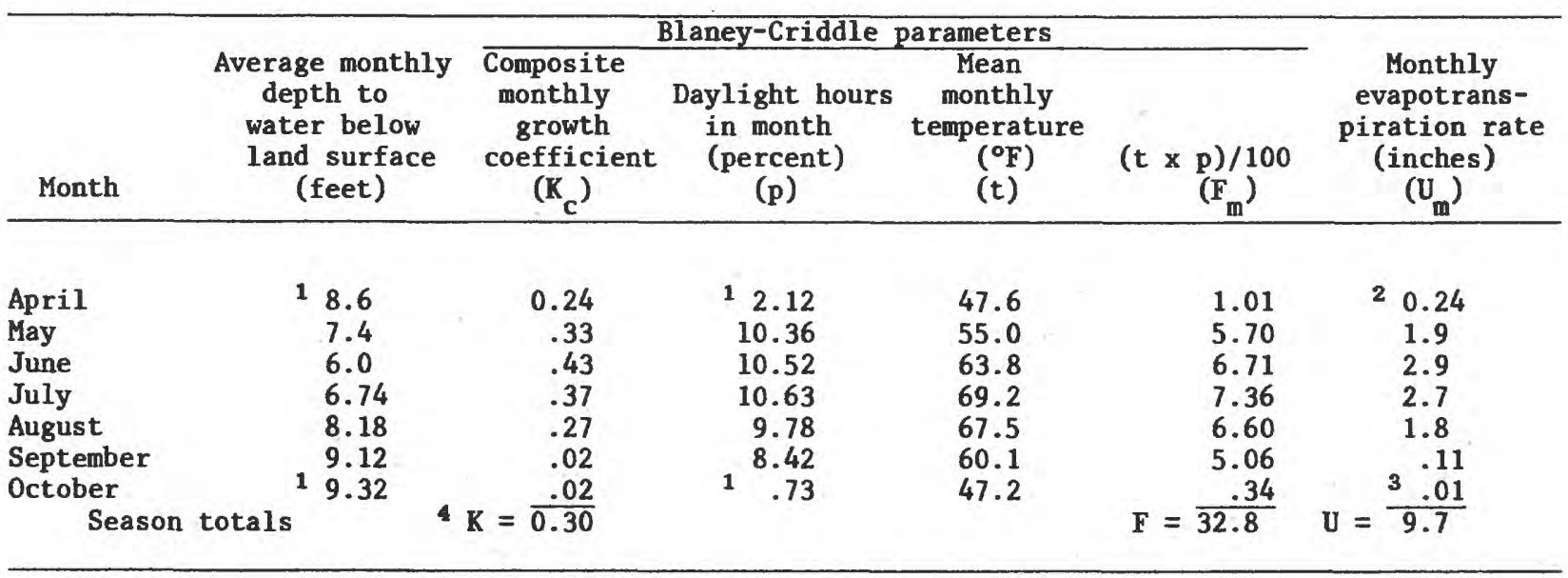

1 Adjusted because growing season did not include entire month.

2 Evapotranspiration for part of the month. Full-month value is 1.0 .

3 Evapotranspiration for part of the month. Full-month value is 0.07 .

$4 \mathrm{~K}=\mathrm{U} / \mathrm{F}$. 
Site 11

Site 11 is located on Donkey Creek near Gillette, Wyo., in sec. 33, T. 50 N., R. 71 W. The well providing ground-water-level data at this site is located approximately 400 feet north of Donkey Creek. The alluvium is 26 feet thick, consisting of clay, sand, gravel and gravel-sized material derived from sandstone, clinker, and coal, and is underlain by the Tongue River Member of the Fort Union Formation. Grass makes up most of the plant life, together with some sagebrush and a sparse scattering of trees.
Six measurements of water levels in the observation wells were made between June 6 and November 15,1978 . September is the only month without a measurement for this period. Estimates of evapotranspiration rates ranged from 0 (adjusted for part of a month) to 2.3 inches per month (table 16).

\section{Site 12}

Site 12 is located along Donkey Creek near Gillette, Wyo., in sec. 27, T. 50 N., R. 71 W. The well providing ground-water-level data at this site is

Table 14. Computed evapotranspiration at Site 9.

[Evapotranspiration values were calculated only for the months when water-level data were available. Depth to water for cessation of evapotranspiration from grass was 13.5 feet and from brush was 15.5 feet]

\begin{tabular}{|c|c|c|c|c|c|c|}
\hline \multirow[b]{2}{*}{ Month } & \multirow[b]{2}{*}{$\begin{array}{l}\text { Average monthly } \\
\text { depth to } \\
\text { water below } \\
\text { land surface } \\
\text { (feet) }\end{array}$} & \multicolumn{4}{|c|}{ Blaney-Criddle parameters } & \multirow[b]{2}{*}{$\begin{array}{c}\text { Monthly } \\
\text { evapotrans- } \\
\text { piration rate } \\
\text { (inches) } \\
\left(U_{m}\right)\end{array}$} \\
\hline & & $\begin{array}{l}\text { Composite } \\
\text { monthly } \\
\text { growth } \\
\text { coefficient } \\
\left(\mathrm{K}_{\mathrm{C}}\right) \\
\end{array}$ & $\begin{array}{l}\text { Daylight hours } \\
\text { in month } \\
\text { (percent) } \\
(\mathrm{p})\end{array}$ & $\begin{array}{c}\text { Mean } \\
\text { monthly } \\
\text { temperature } \\
\left({ }^{\circ} \mathrm{F}\right) \\
(\mathrm{t})\end{array}$ & $\left(t \times \underset{\left(F_{m}\right)}{p) / 100}\right.$ & \\
\hline $\begin{array}{l}\text { June } \\
\text { July } \\
\text { August } \\
\text { September } \\
\text { October }\end{array}$ & $\begin{array}{r}12.2 \\
13.7 \\
14.4 \\
14.7 \\
115.3\end{array}$ & $\begin{array}{r}0.45 \\
.44 \\
.44 \\
.44 \\
.44\end{array}$ & $\begin{array}{r}10.46 \\
10.57 \\
9.75 \\
8.41 \\
1 \quad 1.23\end{array}$ & $\begin{array}{l}61.8 \\
69.2 \\
67.0 \\
61.6 \\
48.5\end{array}$ & $\begin{array}{r}6.46 \\
7.31 \\
6.53 \\
5.18 \\
.60\end{array}$ & $\begin{array}{l}2.9 \\
3.2 \\
2.9 \\
2.3 \\
2.27\end{array}$ \\
\hline
\end{tabular}

1 Adjusted because growing season did not include entire month.

2 Evapotranspiration for part of the month. Full-month value is 1.6 .

Table 15. Computed evapotranspiration at Site 10.

[Evapotranspiration values were calculated only for the months when water-level data were available. Depth to water for cessation of evapotranspiration from grass was 12 feet]

\begin{tabular}{|c|c|c|c|c|c|c|}
\hline \multirow[b]{2}{*}{ Month } & \multirow[b]{2}{*}{$\begin{array}{c}\text { Average monthly } \\
\text { depth to } \\
\text { water below } \\
\text { land surface } \\
\text { (feet) }\end{array}$} & \multicolumn{3}{|c|}{ Blaney-Criddle parameters } & & \multirow[b]{2}{*}{$\begin{array}{c}\text { Monthly } \\
\text { evapotrans- } \\
\text { piration rate } \\
\text { (inches) } \\
\left(\mathrm{U}_{\mathrm{m}}\right)\end{array}$} \\
\hline & & $\begin{array}{l}\text { Composite } \\
\text { monthly } \\
\text { growth } \\
\text { coefficient } \\
\left(\mathrm{K}_{\mathrm{C}}\right)\end{array}$ & $\begin{array}{c}\text { Daylight hours } \\
\text { in month } \\
\text { (percent) } \\
\text { (p) }\end{array}$ & $\begin{array}{c}\text { Mean } \\
\text { monthly } \\
\text { temperature } \\
\left({ }^{\circ} \mathrm{F}\right) \\
(\mathrm{t})\end{array}$ & $\begin{array}{c}(t \times x) / 100 \\
\left(F_{m}\right)\end{array}$ & \\
\hline $\begin{array}{l}\text { July } \\
\text { August } \\
\text { September }\end{array}$ & $\begin{array}{ll} & 9.53 \\
& 10.9 \\
1 & 11.4\end{array}$ & $\begin{array}{r}0.25 \\
.14 \\
.11\end{array}$ & $\begin{array}{r}10.55 \\
9.73 \\
1 \quad 5.89\end{array}$ & $\begin{array}{l}68.4 \\
66.2 \\
59.9\end{array}$ & $\begin{array}{l}7.22 \\
6.44 \\
3.53\end{array}$ & $\begin{array}{r}1.8 \\
.93 \\
2.38\end{array}$ \\
\hline
\end{tabular}

1 Adjusted because growing season did not include entire month.

2 Evapotranspiration for part of the month. Full-month value is 0.55 . 
located approximately 150 feet northwest of Donkey Creek. The alluvium at the well is 18 feet thick, consisting of poorly sorted silt and clay with sand and gravel and coarse-grained material containing clinker, coal, sandstone, and selenite, and is underlain by the Lebo Shale Member of the Fort Union Formation. Grass is the largest constituent of the plant community; some sagebrush and a few trees are present.
Six measurements of water levels in the observation wells were made between June 6 and November 15,1978 . The frequency of measurement at this site is the same as site 11. Estimates of evapotranspiration rates ranged from 0.15 (adjusted for part of a month) to 3.7 inches per month (table 17).

Table 16. Computed evapotranspiration at Site 11.

[Evapotranspiration values were calculated only for the months when water-level data were available. Depth to water for cessation of evapotranspiration from grass and brush was 8 feet]

\begin{tabular}{|c|c|c|c|c|c|c|}
\hline \multirow[b]{2}{*}{ Month } & \multirow[b]{2}{*}{$\begin{array}{c}\text { Average monthly } \\
\text { depth to } \\
\text { water below } \\
\text { land surface } \\
\text { (feet) }\end{array}$} & \multicolumn{3}{|c|}{ Blaney-Criddle parameters } & \multirow[b]{2}{*}{$\begin{array}{c}(t \times p) / 100 \\
\left(F_{m}\right)\end{array}$} & \multirow[b]{2}{*}{$\begin{array}{c}\text { Monthly } \\
\text { evapotrans- } \\
\text { piration rate } \\
\text { (inches) } \\
\left(U_{\mathrm{m}}\right)\end{array}$} \\
\hline & & $\begin{array}{l}\text { Composite } \\
\text { monthly } \\
\text { growth } \\
\text { coefficient } \\
\left(\mathrm{K}_{\mathrm{C}}\right) \\
\end{array}$ & $\begin{array}{l}\text { Daylight hours } \\
\text { in month } \\
\text { (percent) } \\
(\mathrm{p})\end{array}$ & $\begin{array}{c}\text { Mean } \\
\text { monthly } \\
\text { temperature } \\
\left({ }^{\circ} \mathrm{F}\right) \\
(\mathrm{t})\end{array}$ & & \\
\hline June & 6.60 & 0.36 & 10.41 & 61.4 & 6.39 & 2.3 \\
\hline July & 7.42 & .30 & 10.51 & 68.6 & 7.21 & 2.2 \\
\hline August & 7.80 & .28 & 9.71 & 66.8 & 6.49 & 1.8 \\
\hline September & 7.98 & .26 & 8.41 & 61.7 & 5.19 & 1.4 \\
\hline October & 18.06 & .01 & 11.47 & 48.8 & .72 & .00 \\
\hline
\end{tabular}

1 Adjusted because growing season did not include entire month.

Table 17. Computed evapotranspiration at Site 12.

[Evapotranspiration values were calculated only for the months when water-level data were available. Depth to water for cessation of evapotranspiration from grass and brush was 6.5 feet]

\begin{tabular}{|c|c|c|c|c|c|c|}
\hline \multirow[b]{2}{*}{ Month } & \multirow[b]{2}{*}{$\begin{array}{c}\text { Average monthly } \\
\text { depth to } \\
\text { water below } \\
\text { land surface } \\
\text { (feet) }\end{array}$} & \multicolumn{3}{|c|}{ Blaney-Criddle parameters } & \multirow[b]{2}{*}{$\left(\begin{array}{lll}t & x & p) / 100 \\
\left(F_{m}\right)\end{array}\right.$} & \multirow[b]{2}{*}{$\begin{array}{l}\text { Monthly } \\
\text { evapotrans- } \\
\text { piration rate } \\
\text { (inches) } \\
\left(\mathrm{U}_{\mathrm{m}}\right)\end{array}$} \\
\hline & & $\begin{array}{l}\text { Composite } \\
\text { monthly } \\
\text { growth } \\
\text { coefficient } \\
\left(\mathrm{K}_{\mathrm{C}}\right) \\
\end{array}$ & $\begin{array}{l}\text { Daylight hours } \\
\text { in month } \\
\text { (percent) } \\
(\mathrm{p})\end{array}$ & $\begin{array}{c}\text { Mean } \\
\text { monthly } \\
\text { temperature } \\
\left({ }^{\circ} \mathrm{F}\right) \\
(\mathrm{t})\end{array}$ & & \\
\hline June & 4.15 & 0.58 & 10.41 & 61.4 & 6.39 & 3.7 \\
\hline July & 5.52 & .47 & 10.51 & 68.6 & 7.21 & 3.4 \\
\hline August & 6.37 & .41 & 9.71 & 66.8 & 6.49 & 2.7 \\
\hline September & 6.72 & .04 & 8.41 & 61.7 & 5.19 & .23 \\
\hline October & 16.81 & .04 & 11.47 & 48.8 & .72 & 2.03 \\
\hline
\end{tabular}

1 Adjusted because growing season did not include entire month.

2 Evapotranspiration for part of the month. Full-month value is 0.15 . 


\section{SUMMARY AND CONCLUSIONS}

Evapotranspiration rates for the 1978 growing season were estimated by the Blaney-Criddle method for 12 sites within the Powder River basin. Monthly rates were determined and totaled for the 1978 growing season (where water-level data from wells were available). Evapotranspiration rates at the primary sites ranged from 8.3 inches at site 5 to 14.9 inches at site 4 for the growing season; the mean rate was 12.7 inches. The standard deviation was 2.0 inches, about 16 percent of the mean.

Discharge, $\left(\mathrm{L}^{3 / T}\right)$ from alluvial aquifers by evapotranspiration was calculated by multiplying the rate of evapotranspiration $(\mathrm{L} / \mathrm{T})$ by the net surface area $\left(\mathrm{L}^{2}\right)$ where evapotranspiration occurs. The areal distribution of vegetation contributing to evapotranspiration was determined at three sites (3, 4 , and 5) from infrared photographs of the sites. The average discharge for the 1978 growing season was $0.21 \mathrm{ft}^{3} / \mathrm{s}$ per mile of reach at site $3,0.03 \mathrm{ft}^{3} / \mathrm{s}$ per mile at site 4 , and $0.31 \mathrm{ft}^{3} / \mathrm{s}$ per mile at site 5 . Comparison of the mean dischrge, growing season evapotranspiration rates, and area per mile of reach (table 10) indicates that the net surface area has a greater effect on the discharge than the rate of evapotranspiration. Site 4 had the greatest rate of all the sites but the least average discharge per mile of the three sites where discharge was estimated. Site 5 had a 34-percent less rate of evapotranspiration than site 4 but had a tenfold increase in discharge as a result of the net area being about 10 times the net area at site 4 .

Evapotranspirative discharge from alluvial aquifers in the Powder River basin can be estimated if the area of evapotranspiration within the basin is known. Areas of healthy vegetation on the ground can be indentified on Landsat infrared imagery and used to estimate accurately the net area where evapotranspiration occurs. Discharge from alluvial aquifers attributed to evapotranspiration can be estimated by multiplying the area of transpiring vegetation by the mean evapotranspiration rate for the growing season.

The Blaney-Criddle method compares well with other methods. However, it is difficult to assess the accuracy of evapotranspiration rates obtained from empirical formulas using data and observations available for this study.

\section{REFERENCES CITED}

Blaney, H. F., 1954, Consumptive-use requirements for water: Agricultural Engineering, v. 35, no. 12 , p. $870-873,880$.

Blaney, H. F., and Criddle, W. D., 1962, Determining consumptive use and irrigation water requirements: U.S. Agriculture Research Service Technical Bulletin 1275, 59 p.

Cox, E. R., and Havens, J. S., 1974, An appraisal of potential water salvage in the Lake McMillan Delta Area, Eddy County, New Mexico: U.S. Geological Survey Water-Supply 2029-E, 26 p.

Cruff, R. W., and Thompson, T. H., 1967, A comparison of methods of estimating potential evapotranspiration from climatological data in arid and subhumid environments: U.S. Geological Survey Water-Supply Paper 1839-M, 28 p.

Lauenroth, W. K., and Sims, P. L., 1976, Evapotranspiration from a shortgrass prairie subjected to water and nitrogen treatments: Water Resources Research, v. 12 , no. 3, p. 437-442.

List, R. J., 1951, Smithsonian meteorological tables: Smithsonian Miscellaneous Collection, v. 114 (pub. 4014), 527 p.

National Oceanic and Atmospheric Administration, 1979a, Climatological data, annual summary, Wyoming, 1978: National Oceanic and Atmospheric Administration, v. 87, no. 13, 17 p.

1979b, Climatological data, annual summary, Montana, 1978: National Oceanic and Atmospheric Administration, v. 81, no. 13, 21 p.

Rantz, S. E., 1968, A suggested method for estimating evapotranspiration by native phreatophytes in Geological Survey Research 1968: U.S. Geological Survey Professional Paper 600-D, p. D10-D12.

Robinson, T. W., 1958, Phreatophytes: U.S. Geological Survey Water-Supply Paper 1423, 84 p.

Toy, T. W., and Munson, B. E., 1978, Climate appraisal maps of the rehabilitation potential of strippable coal lands in the Powder River Basin, Wyoming and Montana: U.S. Geological Survey, Miscellaneous Field Studies Map MF-932, 2 sheets.

Trelease, F. J., Rechard, P. A., Swartz, T. J., and Burman, R. D., 1970, Consumptive use of irrigation water in Wyoming: Laramie, Wyoming Water Resources Research Institute, Water Resources Series no. 19, 84 p.

U.S. Soil Conservation Service, 1977, Range sitedescription handbook: Cheyenne, Wyo., U.S. Soil Conservation Service, unpublished guide, variable pagination.

Whitcomb, H. A., Cummings, T. R., and McCollough, R. A., 1966, Ground-water resources and geology of northern and central Johnson County, Wyoming: U.S. Geological Survey Water-Supply Paper 1806, 99 p. 